\title{
Grounding the Social Life Worlds - The Case Businesses' Material Space and Social Context
}

The following subchapters provide background and contextual information on each of the investigated businesses. In order to understand the social space, the social processes that occur within the space, and their actors, a description of the business design and spatial outlay is provided. The different parts intertwine each case's description with first explanations about the actors, the internal social life, and the way these businesses are operated. Using material gathered through interviews and observations, they also address the owners' motives for starting and operating their businesses. These descriptions thereby help to establish those practices which create and make the places, and those which make a business owner a public figure.

\subsection{Organic Store}

\section{Background Information on Business Founding and Location}

The two female owners of this business opened their store in late 2012 with the aim of offering organic products to the local community. As long-term Neukölln residents, they were tired of driving around Berlin in search of organic food and products. Both women had a long-standing interest in nutrition and one had already been trained and worked in the organic food field. They opened the business "because we live ourselves in Neukölln, because we eat a healthy diet, predominantly organic, 
inasmuch as possible, this was difficult here for a while and because we simply, I think, had also an interest in giving something to others" (1. 23-26). Because they wanted to ensure enough drop-in customers, they looked for a big space on a highly trafficked street. And because they both have a migration background, they aimed explicitly at providing healthier options to a multi-ethnic clientele. Their goal was to open a "multicultural organic store" (1. $73 \mathrm{f}$.), which provided enough space to gather, meet, relax and hang out. Being able to accommodate parents with strollers and children was also an important factor for them, as one owner had worked for many years in the social sector with young children.

Although they were initially looking for a business location in a more northern part of Neukölln near Kreuzberg, they happened to find an appropriate and affordable business space on Karl-Marx-Straße. In spite of the fact that they describe their business as thriving and as receiving more customers than hoped for, both complain about the hustle and bustle and the often unfriendly and tense people on the street. Because of this, they hoped to open a friendly, welcoming place to in which customers could find calm in the middle of or after an exhausting shopping trip or work day. Unlike many organic stores, their idea was to create a bigger and more open space. They wanted to offer organic products as an option without forcing any customer to buy exclusively organic. "Well, the idea was to create a community

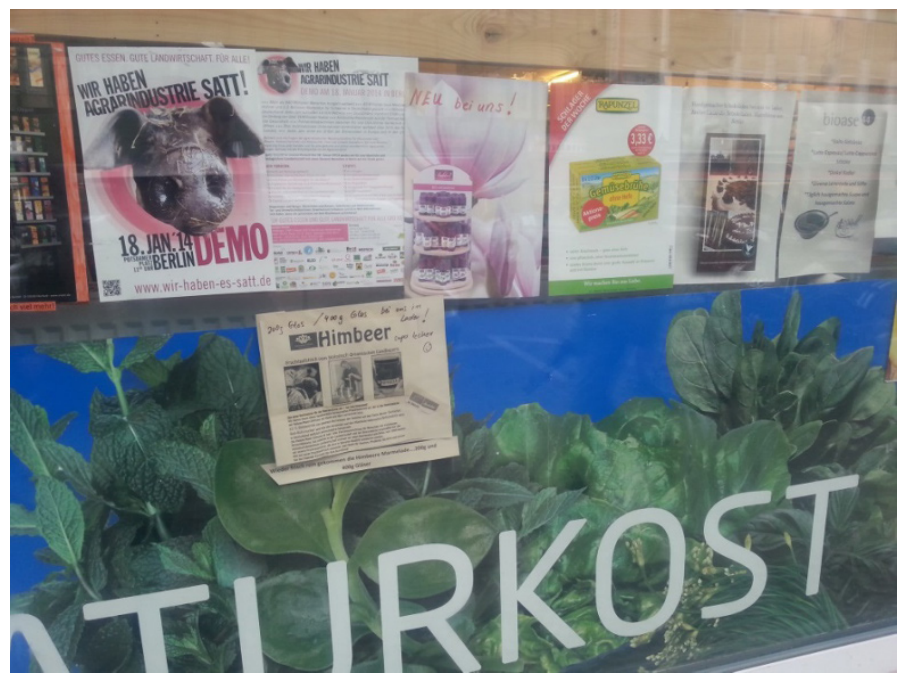

Fig. 16 Front window of the organic store decorated with advertisements for their supplier farms, environmental events, and workshops 
center, a store, a meeting point, shopping with a feel-good-character, that's how we called it"(1.107-113). They combined their savings, a loan from the bank, and the savings of some of their families and friends; and after only after few years of preparation, they opened for business.

\section{Physical Layout and Design}

The organic store is located in the most highly trafficked section of Karl-Marx-Straße, where the street has more lanes and the opposing sidewalk is wider than in the rest of Karl-Marx-Straße. The traffic here is usually congested and drivers fight for the few free parking spots. Because of this concentrated car traffic, bikers tend to ride on the sidewalks, which creates a crowded and confusing traffic situation for pedestrians. The shop is located on the ground floor of a $19^{\text {th }}$ century building between a cell phone store and an inexpensive shoe store. Measuring about $80 \mathrm{~m}^{2}$, it is bigger than typical individually owned health food or organic stores in Berlin. The store's glazed façade is branded with a red banner bearing the business' name above the words "organic store and café." The two owners, along with a team of friends and craftsmen, renovated both the exterior and the interior of the space before opening; and during my first visits in 2013, the store indeed looked and smelled new. They added interior shelving, floor tiling, furniture, and a service counter. The glass front is placarded with posters promoting their organic products and suppliers, events, and tastings, as well as local cultural events, political events (that they support ideologically), and the organic certifications of their suppliers. Next to the entrance, current promotions and sales are written on a billboard. During the warmer months, two or three tables are set out in front of the shop for customers. However, because of the congested sidewalks (due in part to the street construction in front of the store) few customers used them during my observations from mid-2013 until 2016. Some senior citizen passers-by did, however, sit at the tables to rest.

The sliding door opens to what the owner describes as an "oasis of peace." She has trained her employees to remain calm and friendly, regardless of their-or their customers'-moods or problems; and the business is indeed quite a quiet place where people talk to each other in low, friendly tones.

The furniture's color scheme is light brown, white, baby blue, and rose lacquered wood. As seen from the entrance, the product shelves are located in the front and along the right side of the space, and the café is located in the front left-hand corner. On a bulletin board and shelves along the front wall, local residents can leave flyers and advertisements for events, childcare facilities, local programs, jobs, apartments, and the like. This community bulletin board seems well used: The posted flyers are constantly changing and information strips are often taken from such flyers. A red carpet leads from the door towards the center of shop. To the right, baskets 
and shelves are stuffed with fresh fruits and vegetables, allowing for enough space to peruse the aisles with a shopping cart (a row of which are located next to the entrance) or a stroller. Many customers, however, simply park their strollers in the front near the entrance, trusting that no harm shall befall their children. Some customers even leave their handbags and computer bags there.

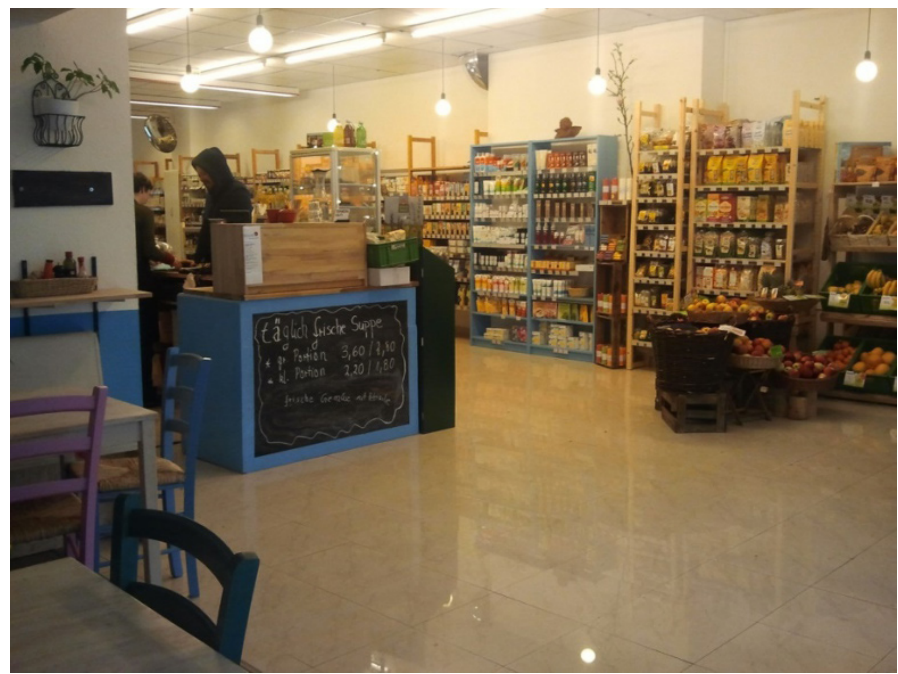

Fig. 17 Organic store's salesroom and counter, view from the seating area

To the left, the coffee corner comprises five wooden tables with four chairs each; a bar with barstools runs along the front window. The left wall opens to the stairways with glass blocks, allowing for additional daylight in the shop. Along this wall, the owners have placed newspapers, local and city magazines and guides, and children's books for their customers to read during their coffee or lunch breaks. The current lunch menu is written on a board behind the counter. Selected gourmet cheeses and pastries are in display cases in front of the counter, and bread and other baked goods rest on racks behind the counter. Despite the café furniture, the shop doesn't offer public restrooms; however, whenever customers or passers-by ask, they can use the private one in the back room for free.

Unlike most other independent organic stores, the shop is organized like a regular supermarket. In the grocery section of the store, fruits and vegetables are followed by cosmetics and household items, sweets, cereals, honey, coffees and 
teas, and other breakfast ingredients. Canned, refrigerated, and frozen goods are in the back. While the prices are slightly higher than in other organic stores in Neukölln, regular customers get a discount membership and the store offers more personalized and expert service.

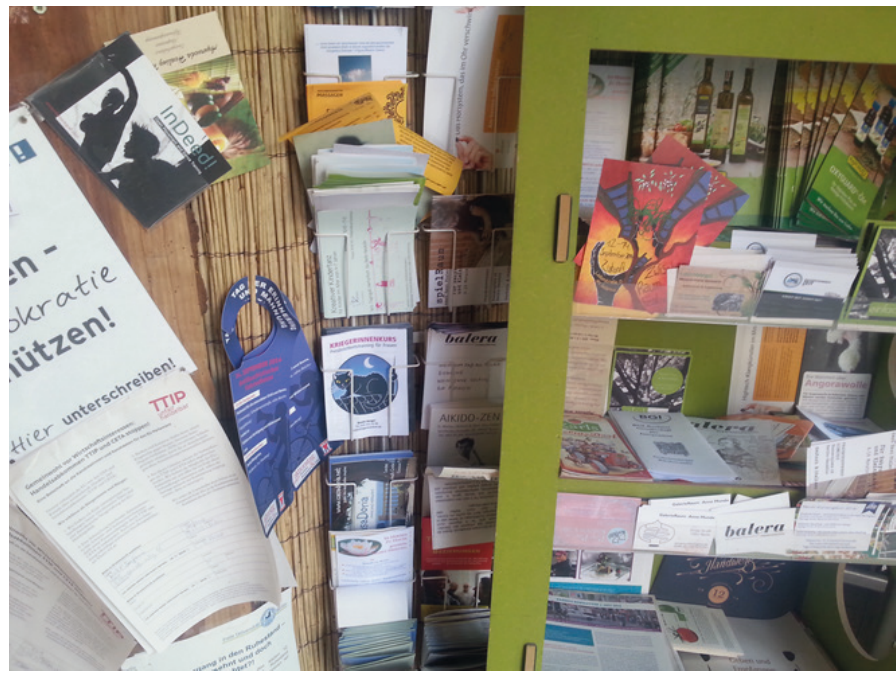

Fig. 18 Bulletin board and shelving with flyers for local businesses and events

\section{Owner(s)}

Before opening the shop, one owner worked as a kindergarten teacher and social worker and had volunteered in organic stores. The second owner was trained extensively in organic food and nutrition and had worked in similar stores before opening her own. Both emphasize their long standing commitment to social and environmental issues: They consider themselves as living vegan, and profess to care a lot about the environment and the sourcing and processing of healthy foods. Tired of losing time biking around the city to different smaller organic stores to buy their own natural groceries and other household wares, they came up with the idea of "becoming business women" themselves.

The interviewed owner is seemd to be more of a public figure and actively promotes the store locally and across the city. During my visits, her younger (and less talkative) partner worked behind the counter or in the store. Both have short hair; and unlike their often very stylishly dressed customers, they wear rather 
practical clothes like jeans and t-shirts (often from organic or fair trade brands, as they mention), along with common green store aprons. Neither speaks with a Berlin or Neukölln accent. I estimate them to be in their 40s and late 30s. In the shop, they both enjoy chatting and serving their customers. They particularly care about making their senior and immigrant customers feel welcome, and they offer service in different languages as needed. According to my observations, both seem to enjoy the presence of children in the shop: They would often give out fruits and (mostly sugar-free) sweets to the children and offer space for parents to park their strollers. Parents also seem to enjoy that their children can play and move around freely in the shop. It is clear that families with younger children are one of their main target groups. Because of the owners' connections to kindergartens and child care facilities, ${ }^{114}$ they were able to convince these local establishments and the children's parents to also order their daily food supply from the organic store. These sales secured their revenue in the first months after opening.

Further, these two self-confident business women are well trained, educated, and prepared with a comprehensive business plan. This plan, as well as their extensive networks to the local authorities and relevant institutions, give them the confidence to believe that they will know how to survive even the tougher times (including the street's reconstruction phase). And, by satisfying their customers' needs, they can enhance loyalty to their business. ${ }^{115}$ Their professional experience and networks built from earlier jobs also facilitate interaction and bonding with very different customer groups.

The owners also project their convictions about certain political topics and have a clear idea of what kind of behavior is appropriate in the store. They also hold strong political and social convictions and hope to have built a space where those beliefs can be lived out. As one of the owners explains:

Well, I believe this theory that people need encounter and people need bodily encounters (l. $1016 \mathrm{f}$.). My favorite word is, where all say about me that I'm such a do-gooder, and yet I was originally a punk and squatted houses, but I have such an 'awareness', I don't need to kick your knee if I don't know you but if I know you and

114 These networks mainly derive from the owner's previous job in the social sector and both owners' local roots in the organic and vegan sector.

115 Both owners took classes at the Chamber of Commerce and one went through a three year apprenticeship to become a self-employed organic dealer. By providing extensive consultation - even if a customer is only willing to spend a small amount of money and offering discounts to returning customers and those who have standing orders, remembering their names, diseases or allergies, and private backgrounds, they achieve a high customer retention and satisfaction. 
there's something I don't like, I can kick your knee and say, well, you know, I don't like this, so this kind of [social] connection (1. 1047-1050).

For instance, they allow homeless and mentally ill people to spend time in the business without buying anything. She says that they only require that all people in the store are respectful of one another and that customers are not disturbed.

Despite the immediate success of the shop, in our interview, they framed their decision to settle the business on Karl-Marx-Straße in negative terms. They seemed to dislike the physical and social condition of the street and both owners suggested that they avoid spending more time on the street than is necessary. They also claimed not to like the street's current commercial structure and regret the absence of "good"116 stores, which offer "good" books, meals, or flowers. They are happy when they can leave the area for some quieter neighborhoods:

Well, spontaneously I have a negative vocabulary [for the street] in my mind, which I'd prefer to leave out. I would simply say it is indeed also adventurous, yes, and by all means such a challenge here, if you walk from the shopping mall back there along [the street] and find five things that were good for you and if it's only these different people here, then you know that it wasn't boring and then you can decide if you want to walk along here again or if you leave it with that (1. 975-981).

Although both enjoy networking and exchanging information with customers, neighbors, and other local business people (during work hours), they rarely extend these (yet homophile ${ }^{117}$ ) "business contacts" to their private space and time. Indeed, they have built their own little world within their shop. A common theme of the therein included people is that they are conspicuous consumers and environmental healthy, and as the observations have shown, distinguish themselves from the street's longstanding residents and businesses. Conversations of customers and staff often circle around the wish for more "new," "higher quality" businesses and how happy they would be if more businesses like the organic store open on Karl-Marx-Straße.

\section{Employees}

During the first few months of my observation period, the store had two full-time and two part-time employees and a cleaning person. The owners, however, hired more employees over the following months due to the high sales volume and ever

116 The term "good" refers here to the quality of satisfying their subjective tastes and needs. It generally also refers to more selected and thus often more expensive goods.

117 Social homophily, as the love of the same, is the tendency of individuals to associate and bond with similar others (Lazarsfeld/ Merton 1954). 
growing customer base. As per the owner, half of the employees have a migration background from other (mainly northern) European countries. My observations noted that the employees were mostly from Anglo-Saxon countries or Germany ${ }^{118}$ and I observed conversations and interactions between owners, staff, and customers in seven different languages. ${ }^{119}$ There are both "male" and "female" employees, most of which are students in their early 20 s to mid-30s, and all of them are fond of and well-versed in organic products. Their physical appearance can be described as casual and alternative. Most employees live in the neighborhood and already knew many customers from other contexts. Their behavior emulates that of the owners inasmuch as they also interact with customers in a familiar - including casual physical contact - yet professional way. However, apart from selected regulars, the staff seems to make the closest connections to rather like-minded or demographically similar customers (e.g. close in age and lifestyle). They also offer special assistance to senior and migrant customers, but not to the same extent or with the same dedication as the owners do. In general, the employees exhibit more or less expertise with organic foods depending on their training and how often they work at the store.

\section{Customers}

The owners explicitly welcome customers with different ethnic backgrounds, not only because of their own so-called migration backgrounds, but also because they have generally always favored spaces where different ethnic groups come together. ${ }^{120}$ The store offers memberships, which cost different amounts depending on customer income level. ${ }^{121}$ Because of this membership system, the organic store has a high percentage of regular customers and a smaller percentage of drop-in customers, among which are increasingly more tourists, as per the owner. Organic products tend to be more expensive than non-organic ones, and most customers must therefore either have higher incomes or, as per the owner, save money for this specific form

118 See the methodology chapter (Chapter 4), where I discuss the difficulty of describing owners' and customers' background appropriately without stereotyping or infringing their personal rights.

119 These were English, French, Swedish, Danish, Turkish, and Arabic.

120 The interviewed owner proudly informed me that she and her co-owner come from Persian and Romanian backgrounds before I even asked the first interview question. Arabic and Romanian are also two of the local more common languages, so their own migration backgrounds help them to serve their non-German-speaking customers.

121 However, both memberships seem expensive, particularly considering the fact that customers must pre-pay for a year, which would be difficult for people who receive social welfare. Low earning or unemployed people therefore most likely don't shop in the store. 
of consumption. The interviewed owner also describes their customers as having a higher educational background; and because of their often daytime shopping hours, most customers seem to be students or self-employed.

When asked about their customers, the owner exclaimed, "everybody, actually everybody," (1.285) and emphasized that a much wider clientele than the "typical LOHAS [Lifestyles of Health and Sustainability]" (1. 267) frequent the store. But during my observations, I noticed customers representing a wide range of ages and ethnicities. I saw adult men and women, ${ }^{122}$ from young people to seniors; entire families, couples, tourists, and local business owners and employees shopping and lunching in the store. Nevertheless, the comparatively high prices and conspicuously different design of the business mean that the business definitely does not attract or include "everybody." As mentioned, the majority of the customers seemed to have a high level of education (according to the store owners and concluded from conversations that I observed in the store). The majority also seemed to be German or from western or northern European countries and between the ages of 25 and 55. In addition to this "middle-class core customer group," more diverse drop-in customers intermingle in the store. According to the owners, tourists mostly come during their visits to Neukölln for a coffee or lunch after having read about the shop in food blogs or tourist guides. In contrast, most Turkish and Arabic customers come in search of organic halal products or because of family allergies. Local business people and employees frequent the store to buy lunch or a snack during their working hours, or they come to buy basic kitchen products for their offices' kitchens. ${ }^{123}$ As a deliberately child-friendly place and because many parents want a healthy diet for their children, parents with younger children gather in the store every weekday, often around the same time. There are usually at least three strollers parked next to the entrance. As per the owner, most customers live on smaller sidestreets of Karl-Marx-Straße and come to the store by bike or foot.

122 It was my general feeling from my own experiences that there are more "female" customers than "male" in other organic stores. I was therefore initially surprised that the local organic store has an almost $50 \%$ male clientele, not only among the grocery shoppers, but also in their café.

123 Unlike the often pricier organic grocery products, the lunch counter offers snacks and hot beverages at a comparably reasonable price. 


\subsection{Main Café}

\section{Business Founding and Location}

The café and bakery opened on Karl-Marx-Straße in May 2011, after the two Turkish-German, male owners renovated the space (which used to be two businesses) into one $100 \mathrm{~m}^{2}$ sized café and bakery. ${ }^{124}$ At the time of the opening, the owners considered their decision to open such business a quite risky one. They worried about the difficulty of raising financial support for their (back then rather new) business concept. The idea of a "tea house" 125 comes from Turkey, where tea houses are common meeting places in which "women and families are also allowed," 126 in contrast to the rather male-orientated and alcohol-selling kahvehane, as coffee or tea houses, where mostly men meet. Their business concept was based on the idea of serving a wide variety of Turkish baked goods made with the highest quality ingredients. The owners are proud of their expensive, high-quality ingredients used in making the many various baked goods and pastries that are available in the café's self-service boxes. The café offers not only pastries, but also hot meals; however, it does not serve alcoholic beverages and is only open for business during the day.

The owners chose to locate the store on Karl-Marx-Straße because they considered the street to be the center of the ethnically mixed neighborhood of Neukölln. As such, they believed that the area would provide a potential customer base that was either already familiar with the concept or was easy to convince of it. Locations where

predominantly Germans are, that is risky and this would have been risky for us, hence if one would have had enough money, then it probably wouldn't have been a problem, but every business comes with risk and one tries to make money as possible and that's why Neukölln, as a location, where many migrants are, fitted for our plans (1.31-35).

The interview partner frames the surrounding neighborhood and his locational decision as "simply because here is such an oriental culture and that ah.... It's also a question of money and that's why it's a risk to open [a business] somewhere else, yes where predominantly Germans are, this is risky" (1. $30 \mathrm{ff}$.). He and his business partner intentionally decided to locate on this particular street in this particular

124 I refer to the business as a café, although it also functions as a self-service bakery.

125 "Tea" is used here to cover descriptions that hint to the café's name, but also stands for the most consumed product in this kind of café. This is why such businesses are often called kahvehane (coffee house) or çayhane (tea house) in Turkey.

126 Again, all quotation marks indicate quotations from the in-depth interviews with one of the owners (August $12^{\text {th }}, 2013$ ) or informal interviews with customers during my field work. 
neighborhood because it promised to provide a significant number of potential customers - Turkish residents.

In addition to the presence of people of Turkish descent, the presence of "self-confident women" (1. 19 - 20) was also important for him, since they form the main base of customers in such tea houses. ${ }^{127}$ The café attracts a variety of ethnic, age, and lifestyle groups depending on the time of the day (business people in the early mornings and during lunch breaks, mothers with young children in the mornings and late afternoons, and students and seniors in the afternoons). The owner initially described their business as meeting place ("Begegnungsstätte"), not just for women, families, or the local Turkish community, but rather for the "local community" in general-a meeting spot for all locals, embedded in the street (1. 15). The owner feels a strong responsibility to, linkage with, and dependence on Karl-Marx-Straße, and considers himself and his business to be part of the street.

[I]t's our duty and we want that it is for all people yes [...] we are part of it, because we don't feel like strangers in this street, yes we feel as a part of this street and we came here to be together with them and they together with us, that's what we do (1. $61 \mathrm{f.}, 128-132$ ).

Nevertheless, he complains that the street can appear uncared for. He has a negative view of the heavy and uncoordinated traffic (l. $555 \mathrm{ff}$.), the "bad" and low-income people who hang out on the street (l. $543 \mathrm{f}$.), and the bad district administrations (l. $6637,235,64,579)$. However, he also admits that these conditions have improved since he opened the business. The longer he operated their café, the more he appreciated the idea that nowhere else people can sit "so long without buying something" (1. 511). Despite bemoaning some of the street's physical and social characteristics (trashy businesses, deviant behavior, low purchase power), he doesn't regret his choice of KarlMarx-Straße-his sales are good and the business is always crowded with customers.

Compared to the other cafes and bakeries on the street, which include chain stores and self-service bakeries, as well as independently owned businesses, in the sampled café the prices for food and beverages are quite reasonable, particularly given the high quality and freshness of their ingredients. ${ }^{128}$ The café offers some hot meals such as Turkish lentil soup, manti (pasta), omelets, salads, kumpir (baked potatoes), as well as full breakfast menus, pastries, buttercream cakes, and a few

127 He frames "self-confident women" as women moving around independently and spending time outside their apartments. Indeed, women of Turkish and Arab descent without male companions represent the (slight) majority of the cafés clientele.

128 The customers mention the reasonable prices as one main reason why they visit the café regularly (often every day as per my observations). 
desserts-none of which cost more than five Euros. Tea starts at less than one euro; a cup of Italian coffee is around 1.50 euros. Customers can either take their orders to go or to stay.

\section{Physical design and layout}

The owner described the interior of the business as a hybrid of "traditional Turkish tea house culture" and German "modern" design. This design is rather typical for such tea houses in Berlin that I would also describe as a sort of hybrid, maybe "Germanized" mixture of a coffee and tea house. ${ }^{129}$ The owner considers the "modern" elements in his shop to be the faux-leather benches and restaurant-standard tables and chairs. The "traditional" elements, in his view, include the bigger tables, the ornamental details and photographs of Turkish harbor cities on the walls, the Turkish pop music playing in the background, the chandeliers, as well as the selection of baked goods and the way they are offered in self-service boxes. He also notes the presence of female service staff as more "traditional." The owner told me that he is a trained architect ${ }^{130}$ and that he has renovated the shop and his private home himself. He's proud of the interior design, which the owner hopes will please "both" of his main customer groups - Turkish and German people. As a "family place" (1. 12), the café provides enough space for strollers in the dining room and offers a diaper changing table and accessible restrooms.

The shop's outdoor signage is written in a calligraphy-style font. Although the name of the café is a Turkish term, the words "tea and breakfast house" written below the name in German communicate the core operations of the business. In the business' third year of operation, the owners also installed an English subtitle on top of the door: "Indispensable address of Turkish tea and [...] culture," seemingly targeting the increasing number of tourists and new residents. The shop's fully glazed façade affords passers-by a view inside, and five communal tables sit before it on the sidewalk. Entering the business through the glass door, a shelf on the left displays Turkish newspapers, free magazines, a small bulletin board, and cutlery for takeaway customers. A flat screen TV programmed to play Turkish pop music videos sits atop the shelf. An L-shaped self-service counter with showcase boxes

129 I also conducted participant observations in similar tea houses on Müllerstraße, Wedding, Kottbusser Tor, Kreuzberg, and Turmstraße, Moabit in order to gain a better general understanding of this type of establishment.

130 Later in the interview, he mentioned that he takes evening classes at an institute of higher education. I question whether his previous training was really in architecture, because he also mentioned a few times during my visits that he does not come from a high educational background. 


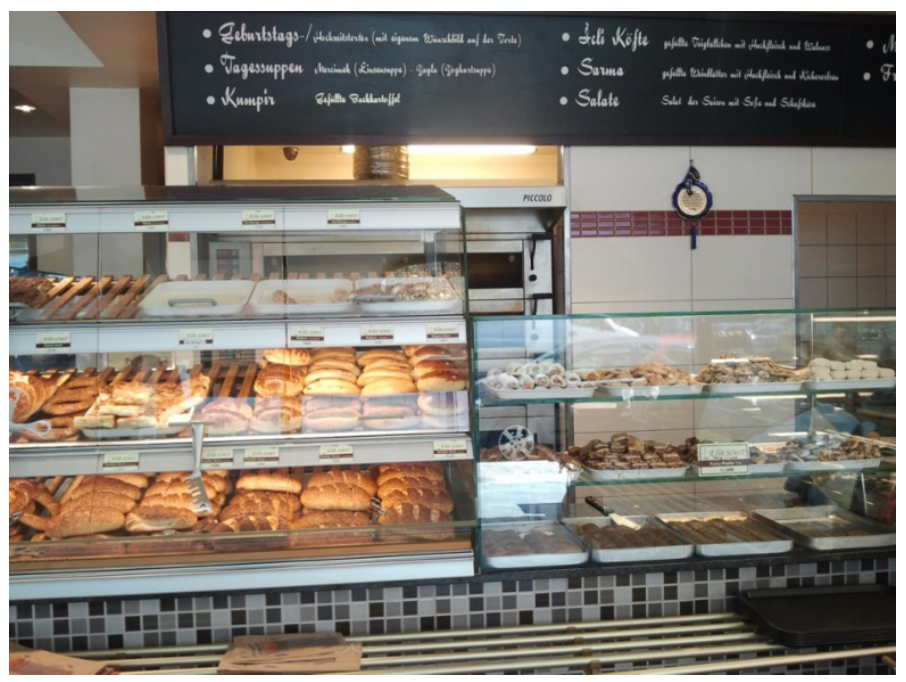

Fig. 19 Main café's self-service station and dessert offerings

displaying different pastries is opposite the doorway. The counter ends with the checkout, which is next to the entrance on the right, and often results in a confused confluence of customers. The big oven is within view behind the counter, as is the entrance to the kitchen, the coffee and tea machines and samovars, as well as a long blackboard describing the current selection-again with Turkish names but described in German-in a rather "Orientalized" font (cf. 1. 30). Sweet and salty baked goods are available in the self-service boxes. These goods include various sesame pastries, sesame rings, and bigger, filled pastries. Next to these compartments, non-self-service treats like baklava, Turkish sweets, and cookies are displayed. The display cabinets also include rather 'Germanized' offerings (e.g. Turkish-style rolls with German-style toppings) with German names such as belegte Brötchen (sandwiches). To the left of the cashier is another glass cabinet, which presents the big buttercream cakes, tiramisu, and Turkish rice pudding to passers-by on the sidewalk.

Because the kitchen door is always open and the oven is located in the salesroom, the business always has a smell of freshly baked goods that wafts out into the street. The café is quite noisy during peak times. Turkish pop music from the TV (tuned to KRAL POP, a popular Turkish music video channel), conversations in different languages, waitresses shouting orders into the dining room, crying and playing children, cell phones ringing, cooking and eating sounds, and table and 
chair sounds blend together to create a bustling atmosphere. The television turns the dining room into a living room-like assemblage, as people stare at the screen whenever their conversation pauses or they need a distraction.

The dining area is comprised of ten freestanding tables and a long bench along the wall, which accompany additional bigger tables for six to eight people. A smoking room in the back has two additional bigger tables and two smaller tables. The tables are made of plain dark wood; as are the chairs and stools, which have burgundy faux-leather seats. The bigger tables are the most desired, in part because the comfortable faux-leather benches along the wall afford a good view of the social life in the café. The walls are painted dark red with gold trim and ornamental designs. There is one wall painted completely gold. An expansive chandelier hangs from the ceiling in the smoking room. Each table in the front room has a small, rather modern lamp; and lights in and around the counter illuminate the goods on offer. Despite the front window, the café lacks light in the back. The observations show that the lack of light seems to please couples and other customers who want to share private conversations. Next to the self-service counter is another rack for returning dishes. On the opposite side, customers use the electronic outlets to charge their cell phones, only randomly checking if their cell phones are still plugged in (but obviously trusting that their phones won't be stolen). The restrooms are on the other side of the small smoking room, as are the stairs to the basement, where the

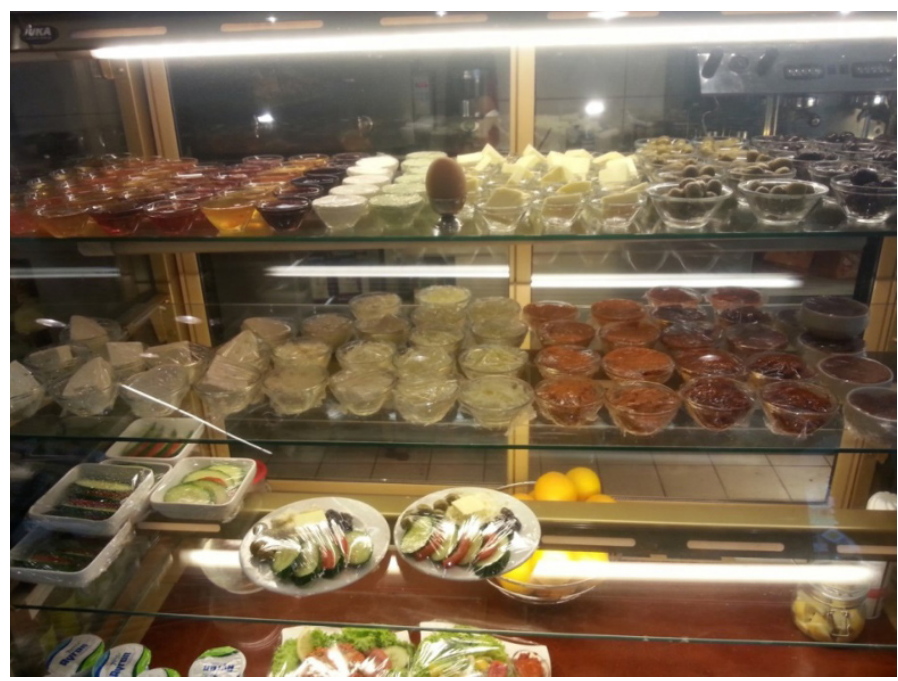

Fig. 20 Main café's counter display 
owners have their tiny offices and other storage rooms, and the back entrance to the kitchen. Paintings of Turkish cities decorate the hallway to the downstairs level. ${ }^{131}$

\section{Owners}

One of the owners is more visible to the public and tends to be more involved with the promotion of the business. He therefore also acted as my main interview partner. The other owner works more as the manager in the back office. I estimate them to be between 50 and 60 years old. Both are well dressed in casual, yet expensive-looking clothing. When he arrives at the shop, the main owner ${ }^{132}$ honks the horn of his BMW, which he usually parks in front of the café, double parking if no parking spot is available. He speaks with a stronger Turkish accent than his waitresses do, most often talking to them in Turkish; and while he knows many customers, his employees seem to know more.

Despite his (increased) satisfaction with Karl-Marx-Straße, he has no interest in living in Neukölln. ${ }^{133}$ One reason is that his image of the street is still a negative one, with its "cheap one euro stores," many "foreigners," "bad behaviors," and "pollution from the traffic" (1. 555 f.). He does, however, view the local business people and his own employees, all of whom live in Neukölln, positively. He insists that he knows more people in Friedrichshain, where he lives, but more people at his place of business know him, where he also spends most of his time. He enjoys the well-known status on Karl-Marx-Straße:

Yes, sure, I'm a business person here and then they all come to this place, also those come who are befriended and other people yes, if only a part of them would see me every day, they recognize my beautiful face, that's so easy (laughing) (1. 615-618).

While his image of Neukölln is improving, before he opened the business, he had a poor view of Karl-Marx-Straße:

131 While standing in line for the restrooms in the hallway, customers chat with employees passing by on the way to the kitchen or taking a rest in the small space outside of the kitchen.

$132 \mathrm{He}$ is also my main interview partner and spent significantly more time in the café's front spaces throughout my observations than his business partner. He is thus the focus of my discussion on ownership.

133 He lives with his wife and children in Friedrichshain, because it's more his "milieu" and fits his preference for a "little bit of a calmer corner." There, he has organic stores "so groceries, I don't buy [them] here, for these I have my organic store" (1. $637 \mathrm{ff}$.), less cheap stores, and better schools for his children. 
I thought there is a criminal with a knife and a weapon in the hand at every corner and always problems and that's how I thought, such a general image, so I thought that it is not very fine [...] ah yes with these cheap stores I always felt embarrassed by them, yet my neighbor from Friedrichshain, she likes it. That you can buy for five seven Euros flip-flops or so. She thinks this is good and with enthusiasm she buys here and [other] things I don't know [laughing] (1. 523 f., 1. $637 \mathrm{ff}$.$) .$

Despite his affable personality, he is upset about the current state of Karl-MarxStraße: The tense traffic and parking situations, along with the "too lively" (1. 539) and overcrowded sidewalks (due to the reconstruction site in front of the café), affect the café's sales. He also complains about the local shopping mall, which he thinks destroys neighborhood social life. ${ }^{134}$ However, his biggest concern is the local administration, which he feels systematically disadvantages, excludes, misunderstands, and disrespects him. When asked what he would like to change for the street, he shouts, "to demolish the committee first [...] and then have new elections" (1. 653).

Unless he is thinking about the local administration or misbehaving customers, the owner is a calm, friendly, and generous host. Both owners are well-respected persons in their place of business, teasing and chatting with employees and customers alike; however, if they aren't satisfied with their employees' work, they tend to use a harsh tone in their criticism. Because they are not as well-versed as their employees in the sales procedures and customer interaction, they sometimes interrupt the working routines and orderly working system behind the counter or in the kitchen.

\section{Customers and Employees}

According to the owner's statements and my observations, the majority of customers at the café are of Turkish or German descent. Around a quarter of customers are of Arabic descent or of other European origins. ${ }^{135}$ The owner and employees regularly donate food to local poor people and don't push customers to make purchases (e.g. 1. 405 f.). ${ }^{136}$ For instance, salespeople and owners are aware that some customers

134 The owner told me that he only has a "basic education" compared to the educational background of those in the administration or urban developers, so he feels disadvantaged and not respected by them. He tries hard to speak in a sophisticated way and to underline his knowledge of architecture and urban planning.

135 In recent years, there has been an increase in Italian, Spanish, and US American residents in the neighborhood. There is also a language school adjacent to the café. Because of these factors, the owners have noticed an increase in such customers at the café, particularly during school breaks and afternoons.

136 The staff knows that many customers live in or close to poverty; therefore, they don't want to raise prices or tell people to leave when they're not consuming. 
collect leftovers or drink the milk on the counter that is supposed to serve those who buy coffee:

Yes, sure, I also saw people who took away the milk for coffee or so from the pot, an employee also told me that, and then they share the milk among them and drank it and so. I also saw this and then I donated it, hence, I mean this is me, my character, I gave them something for their "table" [food bank] (1. 405-08).

Nevertheless, they force beggars to leave the business immediately and they sanction loitering at the outdoor tables.

Customers vary widely across age, income, and milieus. Customers include not only local business owners and employees, but also people working in offices in adjacent areas. Conversations with customers and the owner reveal that the customers range from salespeople and doctor's assistants to teachers, bank managers, business people, and lawyers; most work on Karl-Marx-Straße. They frequent the place mainly in their coffee and lunch breaks, searching for a quick but high quality meal, as they told me. Further, the local business people appreciate having a convenient place to eat and use the café's larger tables for business meetings. ${ }^{137}$ The café's owner takes pride in and appreciates the business people's patronage. Teenagers and students usually visit the café during the afternoons or lunch breaks and most often come in small groups. Some also study or do homework in the café. The lack of free wireless internet might be the reason why very few customers use their laptops in the café (as compared to the other cafés along Karl-Marx-Straße). Most often, if working, customers will spread out writing materials, cell phones, and tablets on the tables. Senior customers also frequent the café for a coffee klatch or to treat themselves to a coffee or tea and a piece of buttercream cake in the company of other senior acquaintances and the waitresses in the afternoons.

Families with small children receive special attention from the owners and employees. ${ }^{138}$ Because the children receive so much attention from other customers and employees, and because the strollers demand others to move out of their way, families represent the most likely group to interact with other customers or salespeople.

137 Particularly business people of Turkish descent frequent the café with business partners from Turkey because of the "high quality" Turkish pastries and teas.

138 In an attempt to make the café a special family-friendly destination, the owners had planned to open a second floor space with toys for kids. The local administration, however, rejected the proposal. The staff does, however, make sure that mothers get hot water to warm the baby food and that crying toddlers get cuddled and treated with sweets rather than disciplined. 
The employees are mainly young women of Turkish descent and most speak both German and Turkish fluently. As one employee emphasizes, they all pay attention to their appearances in terms of makeup, fancy nails, and hairstyles. They wear aprons, not uniforms, and very few of the employees wear hijabs. They describe their clothing as "Neukölln fashion" or "Muslima fashion," meaning trendy, formfitting clothing that covers the back, arms, and legs. ${ }^{139}$ All of the women work part-time; some of them are also completing their education or have additional jobs. The cook and baker are middle-aged men who also wear the café's standard apron. They both speak German less fluently than their female colleagues; but generally, they also interact less with customers. Occasionally the female employees take over all jobs in the café. While these different jobs can be physically demanding - with the heat in the kitchen and around the ovens or just running around the sales and back rooms, winding through the crowded rooms, carrying the heavy trays-as one waitress jokingly told me, they all are well-trained and in good physical shape.

In summary, the café receives customers ranging widely in age, ethnicity, education, and income-a much more diverse clientele than in the other investigated businesses. A slight majority is of Turkish descent and the employees seem to interact with these customers in a slightly more intimate way. Most regulars are local residents and business people, often of Turkish descent. German seniors also make up a large part of the regular crowd. However, the clientele differs greatly according to the time of the day and the day of the week, as do the employees.

\subsection{Pharmacy}

\section{Business Founding and Location}

The pharmacy is most likely the longest standing business (more than 110 years) on Karl-Marx-Straße and is renowned among many long-term residents and business owners. It has been run by the same family for more than 60 years: The owner took over the business from her father, who inherited it from his father. The family originally located the business in a building further south on Karl-Marx-Straße. When that building was demolished in World War II, however, the current owner's grandfather opened an emergency pharmacy inside of an adjacent business. Later, her grandfather and father moved the pharmacy to a location across the street from

139 During quieter times and their breaks, the employees often discuss the "local style" and their style in particular. They used these style descriptions, when I asked about the styles' meanings. 
the business' current location. They were then forced to move to their current location when their previous landlord tripled the rent. As a result of this long history, the pharmacy, the owner, and her family have themselves experienced most of the demographic, social, political, and physical changes in the neighborhood over the course of the $20^{\text {th }}$ and early $21^{\text {st }}$ century. Indeed, the owner herself expressed her surprise at how much the street had changed when she came back to work there.

Fig. 21

Sidewalk in front of pharmacy

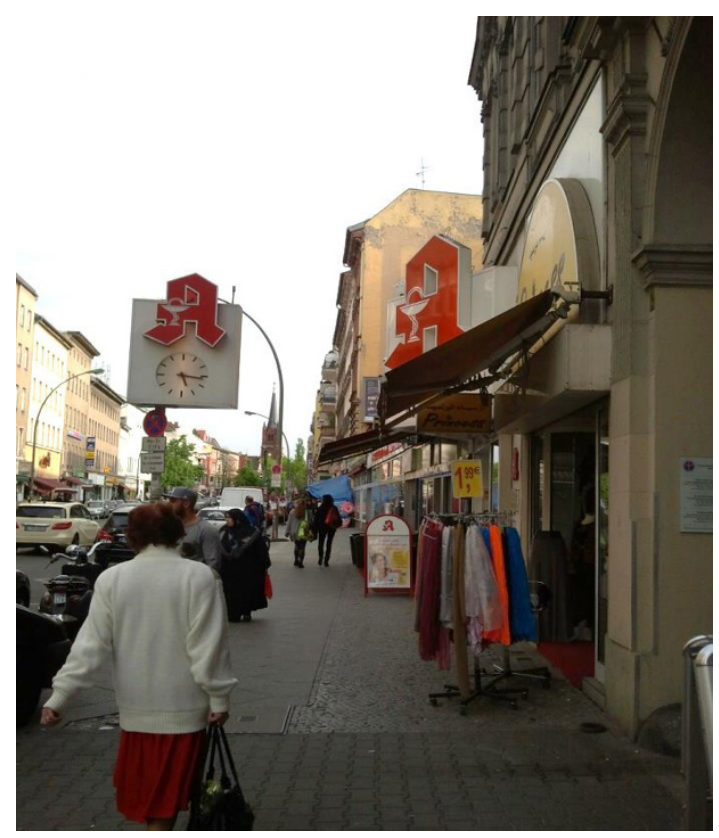

The current owner has a strong interest in her family history and the history of their business in the neighborhood. During WWI, her grandfather owned a pharmacy in Eastern Europe. When he was forced to flee his home, he came to Berlin where he settled in the neighborhood and found a job in the (mainly destroyed) local pharmacy. His son, the current owner's father, took over the pharmacy after his WWII imprisonment and pharmaceutical studies. The current owner did not immediately take over the business after her pharmaceutical studies. Instead, she remained for a while in academia. But when she decided that she wanted to have a 
family, she felt it impossible to combine with her research position. Her father then fell ill, at which point she decided against opening her own pharmacy and started working in the family business instead:

[T] his is not meant to sound negative [...] but you know there was no vision behind, but there are certain restraints behind, or conditions, not restraints, but you jump into it. We're a family clan, family works for us, but this has consequences on how I understand my job, and generally, how I understand the entire life here and yes, that's how I ended up here [...] and this is why I said back then yes, I invest into here I stay here, I continue here and we renew this pharmacy and then we equipped it with latest technology and this was a decision for Neukölln and for our common [enterprise] (1.49-65).

This means that the owner did not decide where to locate the business, but rather followed her perceived family duties and restraints. The family's history thus shaped not only her professional future but also that of her business.

\section{Physical Design and Layout}

The business is located at the liveliest part of Karl-Marx-Straße in one of the street's most impressive $19^{\text {th }}$ century stucco mixed-use buildings. It is squeezed between two buildings from the 1960s, one housing an inexpensive fashion store and the other a low-price café with gambling machines. ${ }^{140}$ The pharmacy owner complained about her commercial neighbors throughout the interview, saying their "shabby" (1. 754 f.) window fronts, business signs, and decoration distract from her own business and would lower the value of all the neighboring businesses. The pharmacy has a limited window front and a small entrance in the narrow building. The entrance is framed by white door frames and topped with a big pharmacy sign and the name of the business. The owner has spent a substantial amount of money to make her business more visible, even installing a sign advertising her business on the street clock facing the storefront.

Inside, the long, narrow, $20 \mathrm{~m}^{2}$ salesroom leads to the back storage room and a stairwell up to an apartment on the upper floor. The salesroom has white shelves on both walls; the counter runs along the left wall and can serve three customers at once. However, because the space is so narrow, customers cannot wait in line. This

140 The ownership and type of business in this particular space seems to change every few months. During my field work, the space has held a wholesale off-brand perfume shop, a kebab take-away, a casino, and currently a gambling café. The-as per the pharmacist "unwelcoming"-clothing store closed in late 2015 and has been vacant since then. The reconstruction of the street also forced the owner to disassemble her exterior pharmacy sign and advertisement. In late 2015, the sign was moved ca 30m down the street. 
enables customer interactions, particularly during the more crowded times. The shelves on the right are stocked with self-service wellness and cosmetic products, teas, and vitamins. The shelves on the left display commonly sought over-thecounter drugs such as medications for coughs and colds, muscle stiffness, and the like. Compared to other (often franchise) pharmacies in the adjacent districts, the self-service shelves display fewer luxury or organic products (e.g. organic cosmetics, sweets, or teas). These products, as per the owner, would demand a higher local purchase power. Most of her clientele frequents the store instead for urgently needed or prescribed pharmaceuticals.

A carpet runs the length of the salesroom, which along with the narrow window, the setback entrance, and the window's decoration amounts to a dark but comfortable and calm atmosphere. This interior darkness and the rather narrow entrance mean that only knowing passers-by or people in search of a pharmacy would easily discover the business. But once inside, the bright ceiling and well-lit shelving easily guide customers through the salesroom and highlight the product selection. A little glass case displaying various tests (for blood and cholesterol levels, for example) is next to the entrance and covered with posters offering advice on nutrition, products, and events. There is no built-in seating, but a few chairs are available for waiting customers.

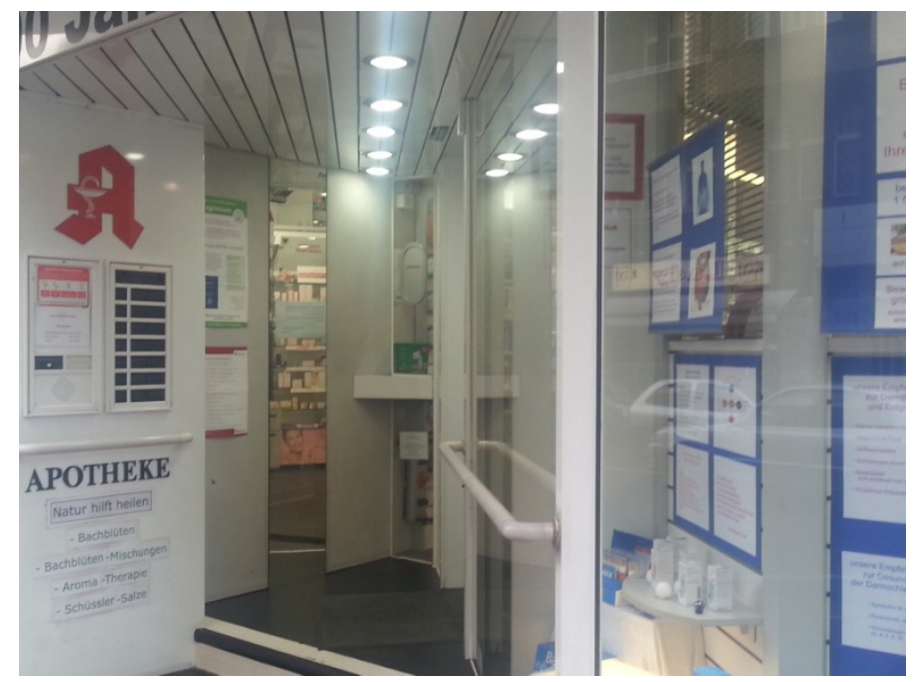

Fig. 22 Pharmacy entrance 
The back storage room is outfitted with an automated system that delivers the requested prescription drugs and products to the salespeople. This elaborate but quick system allows the salespeople to spend more time with the customers. The stairwell up to the apartment and the apartment itself are decorated with little tin figures collected by the owner's father and pictures of Karl-Marx-Straße (from around 1900 until today). According to the owner, her father regularly invited other local business people to these private rooms for afternoon drinks. However, back then, the pharmacy had a two-hour lunch break. Today, the owner and her employees use the back rooms for their (much shorter) breaks and to do the paper work. She also stores decorations and furniture there. The apartment has three rooms, a small kitchen, and a bathroom. The space fosters interactions among staff and contributes to the development of ties among them. For instance, the sofas, wall unit, and coffee table (decorated with fresh flowers) allow them to drink coffee and share cake in a seemingly private living room during their lunch breaks. Inasmuch as the front room lacks privacy and offers a clean, standardized, respectable shopping atmosphere, the back rooms convey a more private and intimate, and thus more family-atmosphere. The owner and her employees also receive private guests and solicitors there, as well as celebrate holidays and staff birthdays there.

\section{Owner}

The owner is an eloquent and educated ethnic German woman around 60 years old, who speaks with a slight Berlin accent and dresses in a pharmacist's white coat during working hours. She is a self-confident business owner, describing herself as successful and effective, and she talks proudly about her business, her family, her employees, and how she operates the pharmacy. She can describe the changes in the neighborhood in great detail and knows the facts of life but is also nostalgic about the independently-owned specialty stores which used to make up a larger part of the business community on the street. However, she also emphasizes that for her, change is a necessary part of cities.

Working in a consultation-intensive business, she puts a lot of emphasis on social interactions with her customers and trains her employees to do so as well. She thus has comprehensive knowledge of her customers and their needs, financial means, family situations, and other background information. For instance, she is aware that many local residents avoid visiting doctor's offices (due to lack of health insurance or money or time). She emphasizes that her pharmacy offers consultations for all people, even though intensive consultation does not always strengthen sales volume or customer loyalty. "Well, there's nothing better than to walk into somewhere and to be able to say hi, because you recognize each other and your needs, I think that's wonderful, yes" (l. 831 f.). 
She feels a strong obligation and commitment to the local population that transcends her business interests. Because of this commitment, she often offers specials on medications that address locally dominant diseases such as diseases related to poverty or old age. Given that she is used to and admires the local ethnic diversity, she takes time to explain all products, ingredients, and potential side effects to non-native speakers in a particularly patient way, as the observations show (compared to other local pharmacies). Her business' new homepage also promotes the pharmacy with the slogan "listening - understanding - helping" in seven languages. Because of her local roots and business history on the street, she appreciates and praises the diversity and liveliness of the street, which she considers enriching. She is a curious and open-minded person and the observations show that she seems to approach all customers and passers-by without prejudice, regardless of their ethnic background, addiction, income, or spending behavior.

However, when it comes to the neighboring businesses, she harshly criticizes the dominance of what she perceives to be cheap, franchise stores - which are often immigrant-owned. By contrast, she praises the arrival of higher-quality, independently-owned businesses - often with "German" owners (1. 169 f.) - such as the newer organic store. She further complains about the adjacent shopping mall and cell phone stores: The first draws customers and diversity away from street, the latter decrease the value and (commercial) diversity of the street.

Compared to her well-connected father, she is only familiar with a few other local business people. But since she is a representative of the German Pharmacist Association, she is well-networked within this country-wide association. Her strongest ties on the street are with the owners of the organic store and the flower store where she shops regularly. Like her, these owners are also business women with local roots and higher educational backgrounds. On her days off, she spends her free time with her family close to her residence in southwestern Berlin. There, her husband takes care of the shopping during the workdays.

Although she spends almost all her time in Neukölln in her business, her networks rarely go beyond her business' building. She has only closer connections with its other residents and those of adjacent buildings, as well as with many customers, framed in the following way:

[I] want to do something for the people, I do this job really with my heart and I want to be there for them and I have the sense that we have unbelievable deficits, also because the doctors have their back to the wall [...] and this or that falls by the wayside (1. 379-384).

She thinks that the more (publicly insured) patients the local doctors receive, the less time they have to treat them. For this reason, she talks with and counsels her 
customers all the more. The character of her ownership can best be described as highly engaged with Neukölln, defending it as a "big melting pot" and a place which "[offers] incredible opportunities" (1. 455 f.). She accepts, welcomes, and cares about all kinds of people who might seek her advice or support, including marginalized groups such as addicts, homeless, or poor people. She sees her business as a neighborhood place:

where people maybe have simply a little more time, interact a little bit, nicer, well this would be my ideal and this is what I try to live here, well you will definitely hear that we are so ostensibly amicable, this sounds always so commonplace, but I come in here and for the ten hours that I spend here I'm in a good mood, even if one has sorrows [...] such a smile opens 1000 doors (1. 399-404).

[T] his matters to me, my customers must be well off, my employees must be well off, and also my family (1. $961 \mathrm{ff}$.).

\section{Employees}

The owner encourages all of her assistants and pharmacists to treat customers the same way:

I follow seriously [...] 'people come first' and I'm a specialist for pharmaceuticals and I take this very seriously and I select my employees depending on whether they take that seriously as well and work on a high level (1. 86-89).

According to the owner, her neighbors and the local doctors appreciate her pharmacy's five full-time, well-trained employees. In addition to their regular training, each employee also has an area of expertise, including one employee who is the expert in veterinary science and another in natural pharmaceuticals. One employee is of Arabic descent and another is of Turkish descent. The owner hired them not only for their technical training and skills, but also because she considers their language skills to be particularly important for her local customers. She also views the diversity on her staff as enriching for her own and the business' "cultural background" (1. 219 f.).

Most of the employees live in the neighborhood. They are all younger than the owner, mainly between 20 and 45 years old. Some of the female employees, usually dressed in white coats, wear headscarves. During my observations, the employees often visit other local businesses for their lunch or coffee breaks and are thus well informed about local shops and changes in the neighborhood. The owner admits that the employees also tend to have more diverse and stronger local networks than she does. All of the employees speak with the local accent, which seems to facilitate chats with local customers, particularly seniors. Hence, the employees have strong 
roots in the neighborhood, which they also use to bond with customers and to ease social interactions and work in the business. The employees as a group can be described as friendly, calm, and welcoming women. They offer sensitive and caring consultation; for instance, they often recommend cheaper alternatives to expensive medications (if available) or give out promotions and free gifts to customers who seem to live with financial restrictions. They greet many of the senior customers by name and gladly assist handicapped customers in and out of the store. During quieter times, they enjoy chatting among themselves or with customers.

\section{Customers}

As per the owner and confirmed by my own observations, the majority of customers are seniors. Parents in need of medication for their children do not represent a dominant customer group yet; however, they are considered a new and growing customer group (because of the neighborhood's demographic changes). According to the owner, more than 40 percent of her customers have a Non-German background (1. 229). ${ }^{141}$ Most customers are of Turkish or German descent, followed by customers of Arabic and East European descent. ${ }^{142}$ This matches my own observations of the clientele. For the owner, the regular customers "[reflect] the street and what I like so much is that regarding the Turkish population that is the third generation here, yes, if you start with the [19]60s" (1. $271 \mathrm{ff}$.). The clientele has changed over the course of the business' long history from being predominantly German and Turkish middle-aged and senior clientele to a more ethnically and demographically varied clientele. As per the owner, the business increasingly receives more "younger people" (1.426) among the drop-in customers and from the residents and neighbors of the pharmacy's building. The staff describes the younger customers as being more hurried, thus often limiting interaction and information exchange.

The owner reported that most of her customers live, work, or shop on KarlMarx-Straße. A few long-term customers, who moved to other districts when the neighborhood was experiencing a low point, still come back to visit the pharmacy. Observations showed that elderly customers mostly frequent the business in the

141 The owner emphasizes that "foreign" customers prefer on-spot pharmacies like hers rather than online shopping due to their lack of German language skills and their need for more face-to-face consultation.

142 The pharmacy offers index cards for all their revisiting customers. The cards include information about the places and dates of birth. With this and because of the extensive consultations, the owner thinks that she can assess pretty exactly her customers' ethnicities. It is not necessary to be a long-term regular customer in order to register all information important for the prescriptions and use of drugs. Because of this policy, the staff has a good sense about the local dominant diseases and health problems. 
mornings, whereas working people come in during the afternoons. The owner confirmed these observations. She also thinks that, in general, fewer customers come in on Fridays and Saturdays compared to other districts, where the fully employed people can only come in after work or on the weekends. Instead, the pharmacy receives customers mainly during the week and work times (matching my own observations of the waves of customers). Handicapped, elderly, and migrant customers appreciate the extensive and patient service and thus prefer this pharmacy over the many others along Karl-Marx-Straße, as per the owner and the local officials.

Compared to many of the other (often franchise) local pharmacies, the investigated pharmacy seems to have found a good business model to serve most local population groups as well as random drop-in customers. The owner respects the neighborhood's changing demographics and actively responds to her customer's special needs. The family's long-term engagement with Karl-Marx-Straße, its businesses, and residents, seem to make the store an anchor for the neighborhood. ${ }^{143}$

\subsection{Flower Store}

\section{Business Founding and Location}

The little flower shop has been in business since 1936. The current owner took over the business in 1985. The owner frames the business as a longstanding and renowned specialty shop. She decided on this location in part because she was born and raised on Karl-Marx-Straße and thus had and has a good understanding of the street, its residents, and the past and potential future economic climate. Her workplace is conveniently located near her current residence in southern Neukölln and she often refers to Karl-Marx-Straße as her "home." Even before having introduced myself and the research, she invites me into her private back room, explaining that

it's always like that, the bakery, the newspaper stand, the flower store, that's always like that, right, yes, somehow they all come over and ask 'have you heard' or 'do you know' or (laughs) [...] Yes, [a neighborhood hub], generally yes. 'Have you heard, this and this guy has died' (laughs) or 'do you know when the funeral is' and so on (1.4-11).

She considers her business to be a social hub, and is proud of her extensive networks with other local "German" (as she emphasizes) business people. She enjoys describing

143 The pharmacy had to close down due to an extreme rent increase of $250 \%$ in late 2017. In September 2018, the store was still vacant, while new businesses have opened in the neighboring business spaces. 
her business colleagues much more than talking about her own business, because she thinks her comparatively smaller business is too small to matter economically for the street. Therefore she also downplays her (extensive) business and neighborhood knowledge. On her business homepage and during the interview, the owner repeatedly points out that her business is a "one-woman-business", meaning that she crafts the flower bouquets and runs the business "with her heart and hand" (as described on her homepage).

\section{Physical Design and Layout}

The business is a tiny (around $35 \mathrm{~m}^{2}$ ) shop on the southern end of Karl-Marx-Straße near the eponymous subway station. It is located on the ground floor of a $19^{\text {th }}$ century building, adjacent to a Turkish barber shop ${ }^{144}$ to the right and a convenience store, also immigrant-owned, to the left. Its decoration and selection vary with the seasons. During my first visits in December 2012, the shop offered primarily hardy plants adorned with Christmas decorations. However, it also offers fresh cut flowers, small flower pots, floral arrangements, and other little souvenirs, gifts, and decorations all year long.

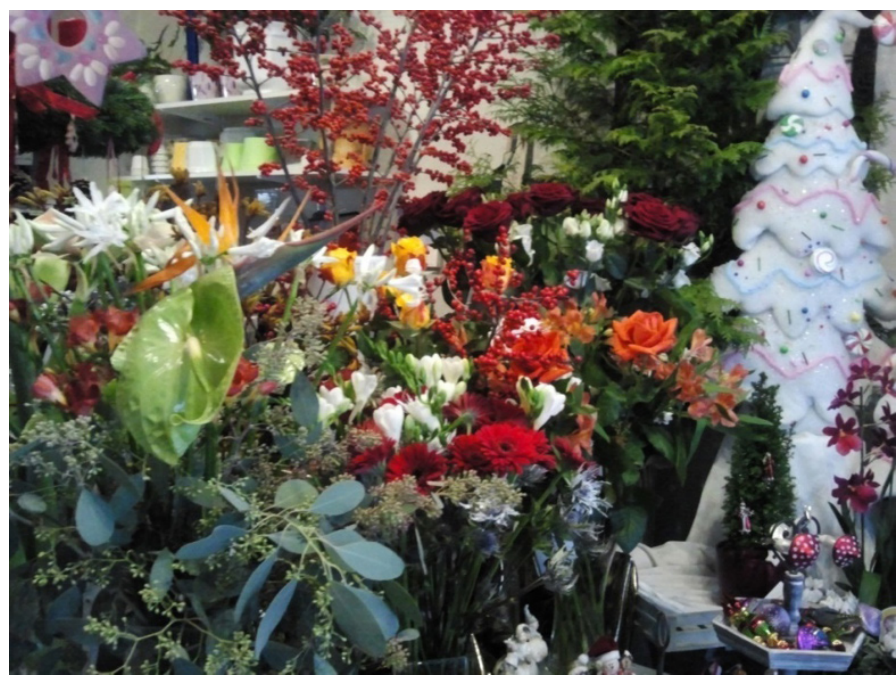

Fig. 23 Flower store's winter window decoration

144 The business sign says „Turkish barber shop“ and “men’s hairdresser”. 
In front of the green tiled storefront, the small outdoor space is also stuffed with goods. A wooden bench in front of the store invites passers-by to rest. I regularly observed seniors and parents with children taking a seat for a couple of minutes before continuing with their shopping trips. Depending on the season, the bench is surrounded by other little trees, wreaths, baskets, seeds, and boxes with seasonal flower arrangements. In this way, the tiny store not only extends its sale space to the street, but also enhances its public visibility.

The narrow shop window's decoration also changes with the seasons. During Easter, for example, spring colored bunnies and eggs adorn the window; during the winter, glittering white candles and blue lights promote the seasonal selection. Throughout the year, the owner fills her front window with floral arrangements, which she exchanges every two weeks.

The exuberant decoration continues in the small but fully-used sales space of the two room business. Narrowly opening to the street, the entirely decorated glass door and front window prevent sunlight from illuminating the sales room (which is in part a tactic to protect the fresh flowers). The high walls are painted dark red and the ornamented ceiling is painted white. Plants, decoration, and single flowers in vases frame the little free spot in the middle of the room. This empty space in the middle of the salesroom allows customers to move or turn around and examine all the kinds of flowers on offer. For special occasions, like when the owner receives particular regular customers or friends or exhibits special flowers, she might also set up a table with a few chairs in the middle of the sales room (usually she invites her favorite regular customers to the backroom, which features a coffee table). The space can hold at most five customers, yet even fewer customers can produce an overcrowded situation.

To the left side of the front room, overstuffed shelves display seasonal potted flowers. During Christmas time, pink and purple flowers and premade decorated pots in white and silver dominate. To the right side, the owner places a little "altar" for each of the Christian holidays or gardening events. At Christmas, for instance, this altar is adorned with Saint Nicholas stockings, Christmas trees, snowmen, angels, flying mushrooms, stars, and other tiny porcelain decoration dolls. During the summer time, potted plants in bright colors are decorated with butterflies and bees. At Easter, the altar is stuffed with decorated eggs, bunnies, and more springlike flowers like yellow daffodils.

The wooden counter is tucked behind this altar so the customers can have enough space to look around. It is covered with tied bouquets, single flowers, and other greenery. Across from the counter, another old wooden shelf is filled with empty flower pots and dolls. A greeting-card-stand sits opposite the counter. Taken in one sweep, the dark, tiny, and crowded salesroom fits the owner's taste and style, conveying the impression that it is a private rather than public space. 


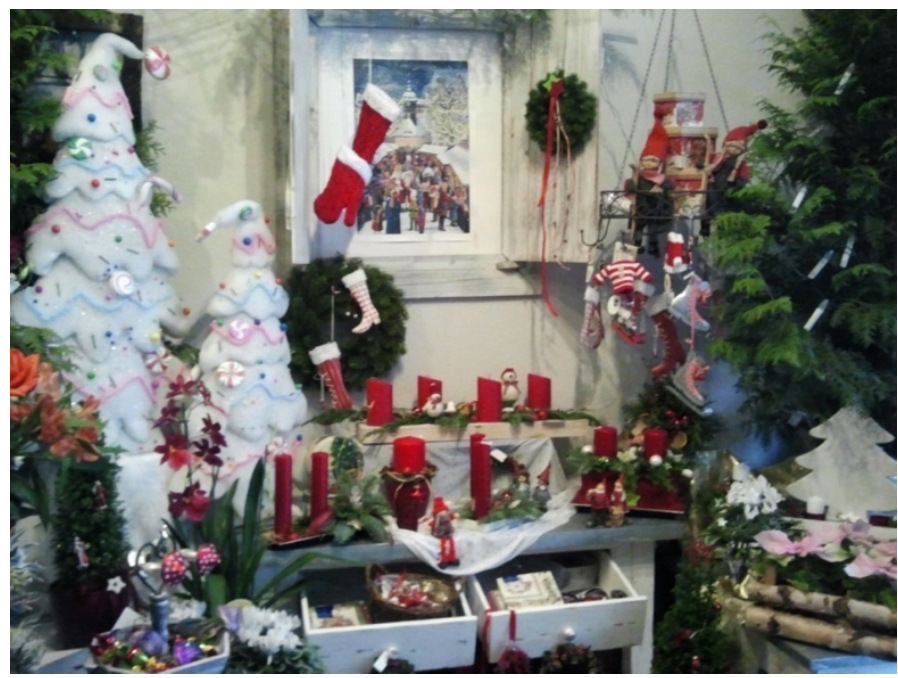

Fig. 24 Christmas decoration in the flower store

Behind the showroom, the back room provides more space to prepare the flower arrangements. Both rooms are kept at a low temperature in order to preserve the quality of the flowers and plants. In the back room, half visible from the front space, the owner has set up a wooden commode to the left, which is loaded with all kinds of paperwork, a radio, invoices, orders, and newspapers. Many postcards of different styles decorate the wall above the desk. To the right is a large work desk with bottles and plastic cans below and colorful single flowers for bouquets or other flower arrangements above. In front of the desk, another big plastic bin is filled with water for cleaning the dishes, which the owner and her visitors use for her daily meals and coffees.

Squeezed diagonally opposite the work table between the commode and a big wooden wardrobe is another lower coffee table covered with a lace table cloth. The day's newspaper and promotional leaflets, breakfast sandwiches, a coffee pot and cups, cutlery, a purse, lighters, pens, a crossword puzzle, a mobile phone, and other personal items are piled up on the table. Two chairs stand next to the coffee table. One is a larger armchair, comfortably covered with lambskin, where the owner usually rests; the other is a folding chair for guests. Another chair is hidden under the desk for hosting additional visitors. The homey decoration and furniture conveys the impression that the owner not only spends most of her time in the business, but that she pursues both work and leisure activities in this one space. Her many 
personal items suggest that the store is the spatial center of her work and social life. In addition, the dining area suggests that at least two people regularly sit to have a chat and a cup of coffee. A big old wooden wardrobe sits behind the dining area and no doubt holds further personal and work items.

An old glass and wooden door leads from the back room to the village-like backyard, where outdoor furniture, dried flowers, and decorations are piled up. An $18^{\text {th }}$ century farmhouse is hidden in this backyard. According to the owner, the house is increasingly gaining interest and recognition in Neukölln and beyond, due to its recent promotion in local newspapers. Hence, she and the farmhouse have received more visitors in recent years. ${ }^{145}$ She also uses the courtyard about twice a year for seasonal events. These events include a little botanic Christmas market in the winter time and a summer barbeque for family, friends, and local business people and residents. The door to the backyard is only closed during the colder months. During the summer, the social life of the business expands from the sidewalk through the sales rooms to the backyard.

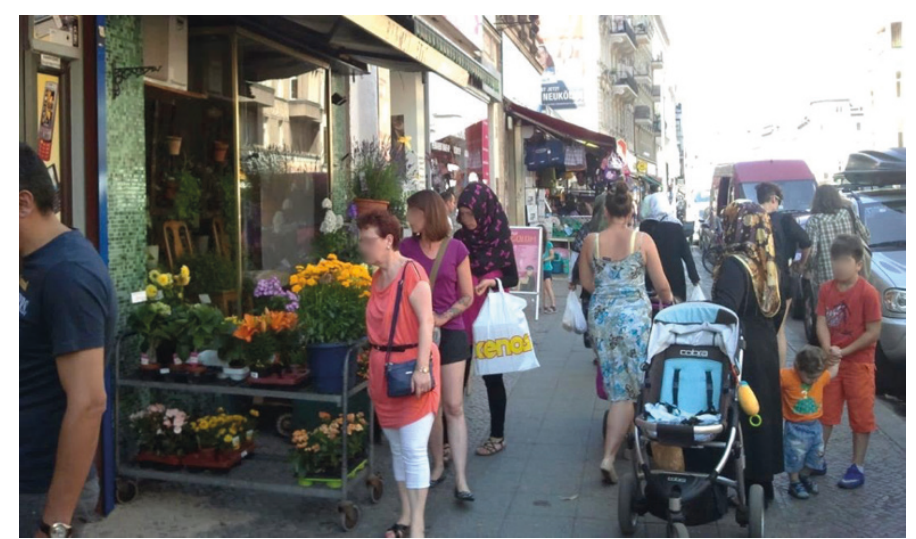

Fig. 25 Flower store's outdoor decoration and goods

145 The house is owned by the district, whereas the backyard is owned by the landlord, but mainly used by the flower store owner. Because she is very proud of the secret architectural icon in her backyard, she agrees to guide visitors there for free. 


\section{Owner}

The owner is a trained florist and had worked in other floral shops in Berlin before opening her own shop. Her family also has a history in the gardening industry. During each of my visits, both the owner and her mother were present in the shop. Because the owner's mother helps with deliveries and cleaning around the shop and spends time chatting with customers and friends, she acts as a second, "informal" owner of the business. ${ }^{146}$ The owner is a resolute and tough character, probably in her late 50s, quite tall, and has a short haircut. She is wrapped in several layers of work clothing, as it can be quite chilly inside the shop. The mother is a small, wiry, short-haired woman, who enjoys smoking and, despite her advanced age, is in good physical shape. Both the mother and daughter speak in a strong local dialect and are proud of being "real Neuköllner[s]": "A neighborhood kid ("Kiezkind") from the beginning to the end" (1.493). The daughter proudly mentions that she was born and raised on the street, close to Hermannplatz. Both lived on Karl-Marx-Straße for decades before moving to southern Neukölln. Today they live in Neukölln's less diverse, quieter, and more residential part, which allows for an easy public transport commute to Karl-Marx-Straße and beyond.

Whereas the mother was skeptical of my presence and worried that my questions might disturb her routines and interrupt her private time with her daughter, the owner responded in a welcoming, open, and trusting way. Immediately after I entered the store, she invited me in to her backroom and gave me a tour. She also introduced me to many of her customers during and after the interview. Her character and appearance might be described as hearty, open, and somewhat talkative. She expresses herself freely and straightforwardly but always pays attention to keeping up her desired image of a respected and important merchant running an honest and reputable business. She clearly takes pride in serving important local people, such as the owners of bigger businesses and local officials.

At first sight, her behavior toward customers fits squarely within Jane Jacobs' description of the merchant as a public character (1961: $68 \mathrm{ff}$.). She has an entertaining personality, a strong sense of humor (a typical Berliner mother wit), and a wide local knowledge that she's willing to share for the sake of the neighborhood. She remains polite and friendly toward me and the frequenting customers, but also reacts in direct and honest way when she has a differing opinion or when she

146 The owner and her mother both live in southern Neukölln, which has a more suburban and residential character. Both mention that they have more social ties, interaction, and relationships on and near Karl-Marx-Straße than in their place of residence, where they only know some of the immediate neighbors. The mother often comes to Karl-MarxStraße in order to cultivate her local contacts and help her daughter with the shop. 
observes inappropriate behavior in her business or on the street. She always keeps an eye on the street while working, not only to monitor her outdoor goods, but also to stay informed about what is happening outside. She uses her impressive personality and physiognomy to underline her statements, particularly when she talks about her role in the development of the street and her role as a business woman.

As a native "Neuköllner", she feels entitled to level direct criticism. Particularly when she talks about the street and its merchants, customers, and residents, she doesn't hesitate to communicate her opinions. She laments over some of the current urban developments, the business practices of many of her "neighboring immigrant business owners" (cf. $1.76 \mathrm{f} .82 \mathrm{f}$.), changing shopping practices of newer immigrant customers and "the foreigners" (1. 539), and her often "lower" sales. While she describes the local people with a migration background often in a xenophobic or racist way, during the observations, migrant customers were served in the same friendly and open way as the ethnic German customers.

However, she is proud of where her business is located and proud of how she fends for herself while operating the store. Although she is aware that her little flower shop only plays a minor economic role and although she bemoans the decreased sales due to the construction site and different shopping preferences of the current street users, she describes her business in an ideal typical way. During the interview, I observed many of the owner's interactions with customers that contradicted her idealized description of the business. Although she clearly has a narrow focus on the "important" local business people who come in as customers, she also happily and politely serves people of all kinds. She frames her business as a "typical longstanding" one (1.32) and herself as a competent, honest, hardworking, and respected business person. She readily shows how seriously she takes her role in the neighborhood and her status as a public character, information trader, care taker, and gatekeeper. Even if she tends to idealize her role in the neighborhood, she demonstrates the devotion with which she pursues her job, offering only "high quality" (cf. 1.525 ff.) products and services, caring for the preferences of her customers, and offering discounts to people who she thinks may have financial problems.

Well, as I said, like the center of somewhere or so, a mouthpiece for [the people] right left or for the customers or something like this, right? But I always think to myself, this is probably the same, this doesn't work differently on other streets or somewhere, if you are a longstanding [business person], somehow. Well, I guess, I don't know, but if you work somewhere for a longer time then you always develop contacts to the right left or you just know each other there, if you go quickly shopping or they come over and get their flowers or [...] I think this works like that in other neighborhoods, too. I mean, you might not expect this here, because this is always very fast-paced, Karl-Marx-Street, yes (1. 243-250). 
For her, social networking and mutual support is something natural that comes with the length of business residence. She also provides broad support, even if only for selected local businesses, and she considers herself to be an honest merchant and frames these aspects of her business as "normal" and "traditional." Her definition of "normal" characterizes the activities of "substantial," "typical," "longstanding," "old Neukölln" (1. 617 f.) businesses. She considers these practices not only part of her own approach, but also as an ethos routinized into the daily life of the other businesses. Nevertheless, it is clear that such categories as "German" (1. 34), "old Neuköllner" (1. 617), "traditional" and "honest/respected," apply only to a small and selected group of stores along Karl-Marx-Straße. For her, "traditional” businesses operating in a "typical" or "honest" way, "network" with and "support" other local (traditional) businesses. But she only assigns these attributes to local businesses owned by long-standing ethnic Germans. With this, she seems to accuse her migrant business neighbors of working in a less honest fashion and being less supportive and less well-networked:

I'd say for the real business people, I mean the Germans [...] they are better networked with each other than with the foreign colleagues. For instance, [with this foreign owner] to the right, with him it is like that [...] well, we [Germans] we talk more to each other (1.33-41).

\section{Customers}

The owner emphasizes her strong ties with other local "German" business owners (1. $34 \mathrm{f}$.), residents, and homeowners, and claims that mostly elderly, long-time residents make up her regular clientele. However, my observations attested to a much more diverse clientele. While the majority of customers are middle-aged and senior women, not all of them are of German descent. The ethnic background of the younger customers varies even more. From the owner's perspective, the clientele hasn't changed widely over the years, but as my observations show, her regular clientele aged along with the owner. Interestingly, the owner did not emphasize her drop-in clientele in the interview; however, during my visits, most of the observed customers belonged to this category. The owner thinks that all of her customers live on or close to the street and flower store, or visit the street because of work or appointments. This conclusion was also confirmed by my discussions with customers.

Another customer group, which includes local businesses, offices, and residents, shops via regular orders. These customers frequently order flower bouquets or arrangements for their work spaces or festivities. Because of the regularity of such orders, the owner believes that she has a good feeling for these local needs and tastes: 
These are, well, I would say $\mathbf{8 0} \%$ German and among which certainly $\mathbf{5 0 \%}$ can afford themselves a little bit, well, I'm not a cheap store and no mass-produced goods or so and this comes at a price and one or two cannot afford this or not in large measure or yes, howsoever, and yes, the rest is then maybe an impulse purchase or so [...] and many young people come, students or so, now (1. 205-209).

The customers do not physically appear to belong to a specific class or income level. On the basis of their spending habits and clothing styles, most drop-in customers and some regular customers do not seem to have a lot of money, but reward themselves with the little luxury of having fresh flowers at home. As per the owner, younger customers and customers with limited financial resources often prefer "cleaner" and "naked" (1.553) flowers. She thus provides more "simple" or "natural" flowers compared to the bigger and more expensive flower bouquets her competitors sell in wealthier neighborhoods. I concluded from my observations and conversations with customers that many buy simple flower bouquets because of their taste and stylistic preferences and not because of their limited resources. They regard the owner's displayed flower arrangements as rather kitschy, fussy, and old-fashioned; however, they praise the arrangements and the business' design for its nostalgic feel and authenticity. Despite the owner's irritation toward many of the demanded items with their puristic styles, she is willing to and serves any customer, regardless of their ethnic background, financial means, or tastes.

There are around two to four senior residents who visit the business once or twice a week with the clear expectation of socializing in the store. One woman, who comes in almost daily, deserves a more detailed description. I call her Mrs. B. She is a 90-year-old (in 2012) woman who lives in the corner building next door to the shop. Her family owns the building and the music store located on the ground-floor of the building just a few meters down the street, which is operated by her sisterin-law (who is also over 70). Even before Mrs. B. enters the shop during one of my visits, the owner, acting as an honorable merchant, talks about her reverently and respectfully. Her customer's family has run the music store for 100 years and has strong roots on the street and in the neighborhood. ${ }^{147}$ The flower store owner is clearly proud to have Mrs. B not only as a customer, but also as a part of the shop's regular social circle (1. 56, 116 f.). She feels vindicated as Mrs. B. enters the store during my first visit. She proudly greets her customer, nodding at me to confirm her prior statements about her good networks with the longstanding business community. She treats the other members of her regular social circle in the same way. The owner describes these women as "venerable Neukölln people" (1. 662 f.),

147 The music store has opened in 1919 and had to close after an act of incendiarism in early 2018. 
who were born and raised on the street and are either current or former building or business owners.

Mrs. B. is well-dressed and dignified, but old and feeble. During my first visit in early December 2012, she came to pick up a flower arrangement that she had ordered. She was supposed to pick it up the day before, but had not felt well, so she wanted to pick it up now (l. 115 ff.). According to the owner, her visits always follow a routine procedure. Whenever Mrs. B. ordered flowers arrangements in recent years, she picked them up late and steered the conversation toward her physical health. When she drops in without having pre-ordered, she usually surveys the shop for new flowers and plants, seemingly knowing most items already, and chats with both the owner and her mother about the local news. In part due to her advanced age, she never seems to be in a hurry. The social exchange between the owner and Mrs. B. conveys the impression that the chat is as important to this regular as the purchase. When she discovers me, she shows high level of interest in my visit, while considering me as a disturbance to the usual atmosphere and business interactions. She eyes me suspiciously and curiously. Despite her slight irritation at my presence, she chats to the owner and indirectly to me about her physical condition for a couple of minutes before exchanging the local news and gossip.

In addition to elderly women like Mrs. B. who make up the core of the flower store's regular clientele, the owner describes her customers as mainly ethnic German and more affluent. In her opinion, people buy flowers either as presents or for their own homes, thus qualifying such purchases as luxury goods. In the same vein as she stereotypes and generalizes different categories of business owners and street users, she also distinguishes between "Germans" and "foreigners" (1. 34, 82, 539) for the street's customers. She identifies her customers as wealthy and "German." The main categories she uses to differentiate between customer groups are "German" and "foreigners" and "people that can/cannot afford something" (1. 206), "longstanding" and "new" customers, and "young people," whom she describes as "students" (1. 209). She sees the young people as the source of neighborhood change, which she seems to like due to her expectation that the "newcomers" will potentially soon earn enough money to spend it more in her own business (1. 216 ff.). Students/young people are signifiers of neighborhood change for her. However, so far she doesn't consider them a substantial market segment, as they tend to only buy single flowers.

In summary, the flower store's clientele can be sorted into a few groups: the long-term regulars, who are older ethnic Germans and have a long history on KarlMarx-Straße; local businesses, who place regular orders; and drop-in customers from various ethnic, age, and income backgrounds. The most intimate interactions occur between the owner and her regular customers; however, her reputation as a 
caring person or neighborhood figure also expands to other local businesses and residents, who approach her as a source of information.

\subsection{Butcher}

\section{Background Founding and Location}

The investigated butcher's shop has been in business for over 70 years. The current owner came to the store as an apprentice in 1997 and took over the business in 2007 when the previous owner fell ill. Although the apprentice had only just finished his three-year training, he had convinced the former owner of his talent and was thus asked to take over the business. However, he was only 22 at the time and had no management experience. His main goal was simply to keep the business going and keep its staff in secure jobs. As he recounts:

I already knew this store, I knew what happens here, what moves here, that the store is deeply rooted in the neighborhood. Certainly, very importantly, we have many many regular customers, who live around here. We had and still have a very good reputation, also Berlin-wide, and that's why I thought to myself, this can be something, this wasn't like I tediously had to work out a new circle of customers, but I could draw on an existing circle of customers and yes, this has encouraged me then to take this step and in the course of the years, it's already 16 years [2013] ago and through the years the clientele has changed, of course, has further developed, the old ones passed away, new ones appeared. The whole district has experienced enormous change since then and I managed it throughout all these years, to still work successfully (1. 53-63).

The business is located just a few steps away from Karl-Marx-Straße on a historic cobblestoned square that leads to the historic "village" of Rixdorf. But the butcher and his staff consider themselves part of Karl-Marx-Straße, as does the media and other business people. In the square, a farmer's market takes place twice a week and draws many additional visitors into the shop, but the store attracts mostly the same local clientele that frequents the stores on Karl-Marx-Straße in general.

\section{Business Design and Physical Layout}

The butcher's shop has a glazed façade and door. A blue and white striped awning is printed with the name of the business and protects the salesroom from too much sunlight. On the sidewalk in front of the shop, a display board announces the lunch selection (two or three warm meals for around three to five euros, mostly typical 
German comfort food such as stews, meatballs, and fricassees). Additional signage taped to the windows promotes the butcher's catering and party services as well as their current sales, local cultural events (e.g. theater, neighborhood meetings), newspaper articles about the shop, and various awards. The entire salesroom is, however, still visible from the street.

Inside the $25 \mathrm{~m}^{2}$ salesroom, the white tiled walls are decorated here and there with old paintings of pig heads, billboards, and certificates. Smoke-dried sausages and hams hang from racks along the walls. On the right, further shelves display canned and bottled goods and mixed spices made at the shop. The counter and display case run along two of the three walls and display a huge variety of meats and sausages. Raw meats are displayed on the left side, and sausages, salads, and processed meat products are displayed in the middle. The around 40 different products include liverwurst, black pudding, white pudding, salamis, blood

Fig. 26

Counter in the butcher's shop

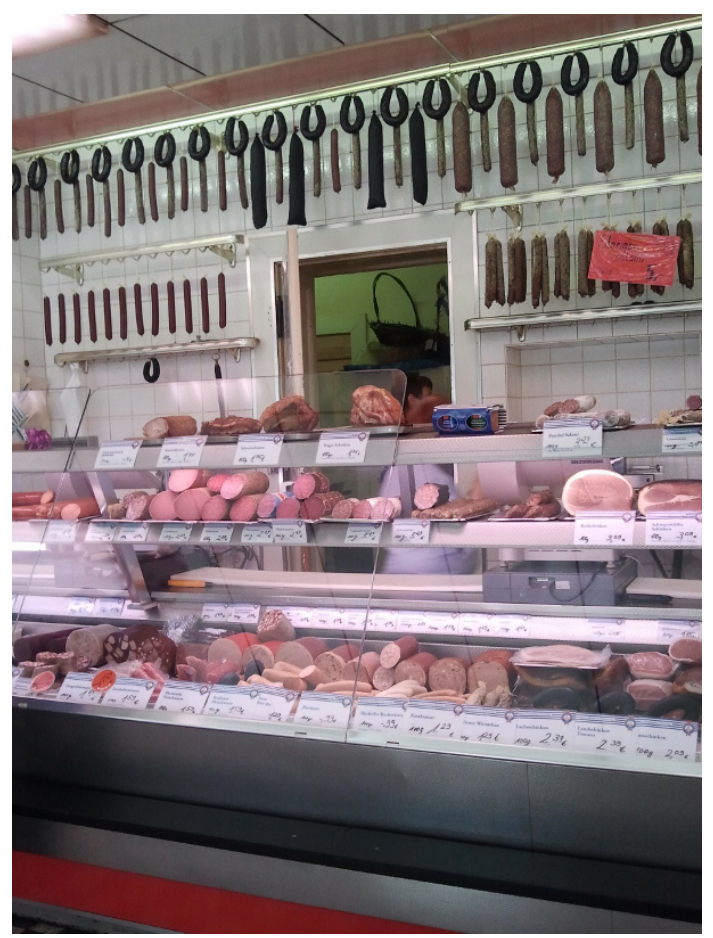


sausages, ${ }^{148}$ bologna, Vienna sausages, pork roast, and roast meat sausage, as well as house-made potato and pasta salads and eggs from a local farm. Along the right wall, three standing tables are decorated with napkins, tablecloths, and little blue and white flowers. These tables are most crowded at lunch time.

The back wall opens to the back rooms, where workers prepare the sausages, hot meals, salads, and other processed goods. In addition to the spacious preparation rooms, the butcher's office, where he and his colleague do the paperwork, receive orders, and manage the online shop, is also in the back. The office is stocked with folders, calendars, papers, and notes. My first impression from the observations was that the business is making good money and the owner received several calls concerning his online shop and pending orders during the interview. ${ }^{149}$ The owner spends most of his time in these back rooms, preparing meat and sausages, receiving telephone orders, ordering his own ingredients, and supporting his staff.

\section{Owner}

Unlike the owners of the other investigated businesses, the owner of the butcher shop "grew" into the ownership. Over time, he earned the title of master butcher and learned how to operate the business. However, the owner admits that although he grew up in a butcher family, it was not his childhood ambition to become a butcher. The owner is in his late 40 s. He is slim and sporty and speaks with a light Berliner accent. He is friendly, witty, self-confident, and very proud of his business and well-trained employees. He also has a strong sense of Neukölln, its history, and its reputation in the media. In my first telephone conversation with him, however, it was hard to convince him to meet me for an interview. He told me that he had had bad experiences with journalists and academics writing about "his" district, since most of the coverage tended to reinforce the bad reputation of the neighborhood. He remained somewhat reluctant and skeptical until after our first meeting and he continually made it clear that he is tired of the negative perspectives on Neukölln. He is upset that other parts of Berlin look down on the local population and he strongly defends the neighborhood. He thinks he is one of the few local business owners who is proud of the neighborhood's ethnic diversity and is sympathetic

148 The butcher received quite a lot of media attention after winning a prize for his blood sausage. Since then, chefs and private individuals from all over Berlin and beyond frequent his business and order his sausages online.

149 During these calls, he allows me to listen in on the speaker phone. The phone and in-person customers don't only ask about product information, but also for recipes; and the owner always answers patiently and in detail, despite his big work load. It is clear that he takes pride in his products and his shop's popularity. 
toward the local poorer population groups. He perceives the neighborhood as still being a working-class, residential area. He knows that most locals manage with little money; nonetheless some are still willing or save money to treat themselves with fresh meat. He is also aware that the neighborhood is changing rapidly, and that many "students," "young persons," and "job starters" (1. 166 f.) are moving into to the neighborhood because of rising rents in other parts of the central city. He likes that the "wonderfully beautiful" old buildings in Neukölln are "still affordable" (1. 192). As a business man, he welcomes any new resident as a potential customer, and many of the newcomers contribute to his revenue.

In sum, he actively defends the neighborhood as a much less conflicted, but more "attractive" business location than many other parts of the city.

[H]ere, it is about togetherness [...] because they [migrants] have settled here, partly also in different generations and this is the attraction of this area, right. I always perceived this as attractive these different people this is sometimes also really funny, right, also these different mentalities, right, this serenity, right, we could cut a piece off from this southern - or even better - from this African serenity sometimes, really lovely, just lovely. And I don't need to go away on a trip to get to really know other cultures, because I have them in front of my door [...] [in the other districts] you only get the touristy [life] to see while here, you get to see the full life of people in everyday life on an everyday basis (1. 394-405).

During our first phone conversation, he continually tested my intentions by probing my knowledge of the neighborhood and asking many ("gotchya") questions. His kind openness and laid back nature therefore surprised me when we first met in the shop. And unlike his tone made him seem in our telephone calls, he turned out to be a nice, comforting, and trustful interview partner. However, during the interview, he continually pushed the conversation in other directions than my questions, despite my attempts to direct the process.

The owner himself lived in the neighborhood during his training in the 1990s and has only good memories of this time, the local people, and the living conditions. However, he also mentions that tensions became aggravated and the neighborhood hit a low point around 2003 until 2005, when many residents left the neighborhood for "better" and "finer districts" (1. 96). The remaining residents shopped less and many businesses around his shop closed down. Despite his fondness for Neukölln and his own residential history in the district, he now lives in an upper-middle-class and less ethnically diverse district in West Berlin. He moved there in 2003, when he had children and needed more space. Since he had always planned to own a house, he bought one in a "calmer" and "greener" (1. 619 ff.) district with savings from his extended family. He says his home's location near green spaces and lakes allows 
him to take little vacations despite his intense work schedule, which prevents him from going on longer trips out of town.

\title{
Employees
}

The butcher's shop has ten employees (2013), most of whom have worked there a long time, some of whom even for the previous owner. To have the same faces at the front counter and the same reliable cook enables the owner and his staff to maintain a feeling of stability, loyalty, and closeness with regular customers:

\begin{abstract}
They all know the peculiarities the customers also know in detail the peculiarities of the saleswomen, this is still [butcher's name], the face behind the sausage, this old guy. Even I belong to the inventory there, the sausage tastes the same as it did last year, as five years ago, as ten years ago, as 20 years ago, this is smoothly made the same way. Here, the mirror is crooked, the tiles are chipped, right, the counter is ageing, but that is exactly what the customer like, that matters for the customers, yes they really say that. We made a customer survey, 'it should remain exactly like it is', right, this counter is such an energy guzzler, nobody builds something like this anymore today. And this is why this [shop] is a real anchor, if you had a bad day or if you consider everything is in motion [...] Humankind strives after stability, he just needs such a few stable [meeting] point [...] they desire a piece of stability that is first and foremost a home, right, and then such businesses like ours, it doesn't change $[. .$.$] and this is our success recipe if you ask me (1.293-309).$
\end{abstract}

Like the business front, the signs, bags, and wrapping paper likewise sport a nostalgic design. The owner feels that his customers like the old-fashioned design and atmosphere of the store and would reject any changes (e.g. 279, $297 \mathrm{ff}$.). ${ }^{150}$

During all of my observational visits to the shop, at least two or three saleswomen were working simultaneously, with one behind the meat counter and one behind the sausage counter serving the lunch customers. They are well trained, have extensive knowledge of each of the products and their ingredients, can recommend recipes, and provide storage advice. They also provide personal recommendations. All of the salespeople speak in the local dialect and most are in their 50s and 60s. They wear white butcher's aprons. Their behavior can be best described as a rough politeness. They are direct and straightforward; and their service is fast and attentive. Their interactions with regulars always involve teasing and humorous comments from both sides, particularly between the male lunch customers and the female staff. The saleswomen already know what their lunch regulars will order and ask their regular and returning customers (after greeting or a small chat) if they'll have "the

150 However, two years after the field work has finished, the store's front window was fully renovated. 
usual," or "as always," "the classic"? These interactions reaffirm the customers' status as regulars and reinforce the long-term relationship with the business. The saleswomen told me that they are proud of knowing their customers' preferences. They also enjoy ironic and teasing conversation with new and less frequent customers. They call most female customers, including me, "young maidens" (regardless of their age) and ask for customers' "desires."

Like most employees of the long-standing businesses on Karl-Marx-Straße, the saleswomen become rougher and blunter when customers dawdle or are unsure of their order (except when dealing with their older, regular customers). This practice is widely accepted among regulars and returning customers, but irritates many new (and non-Berliner) customers. Nevertheless, their interactions with customers reveal their caring nature, often asking questions about the customers' dogs, families, children, physical state, jobs, and so on. Their chats also show that they worry about (regular) customers, for instance, if they haven't been in the store for a while or if they look to be in bad shape.

Most of the saleswomen and the (male) butchers started working for the butcher's shop as young apprentices. They have thus known each other and many of their customers for years and even decades. They chat with each other almost always during my visits, continuing their private chats and laughter when customers enter or are co-present. This practice adds to the private atmosphere of the butcher's shop.

\section{Customers}

The customers range widely in ethnicity, age, and income. According to the butcher, one third of the customers are long-term residents who live near the store and arrive by foot or bike. However, gourmet customers and tourists also frequent the business because of its high profile and acclaim. Women mostly frequent the store during mornings and afternoons, whereas male customers tend to visit the store during lunch and in the late afternoons. Regardless of ethnic background, most speak with a Neukölln accent, which indicates a long-term residence in the neighborhood. For the owner, a "classic local has a diverse background," no matter if in the first or fourth generation. Although many long-term customers left the neighborhood during the latest phase of neighborhood decline in the mid-2000s, they continue to visit the store on a regular basis. Together, these more distant shoppers make up another third of the clientele.

While many customers have aged along with the store, the shop also attracts the newer and younger residents. The owner says that 30 percent are "students" and "young people," who, have often grown up in the southern parts of Germany (where people are more able, willing, and used to spending money on high quality food, such as traditional hand-made meat products). These customers appreciate 
the wide selection at the butcher's shop. Even if they cannot afford to buy as much or as often as some of the elderly customers, "by now", the younger customers "ensure a lively exchange among the customers" (1. 196 f.).

The owner and sales staff pay particular attention and offer special service to senior customers and lunch customers, whom they often know by name. They consider these two groups to be their main regulars. They are also familiar with these customers' educational, professional, and family background. Most lunch customers are men who work in the area or live alone in the neighborhood (e.g. students, retirees). Among them are white-collar and blue-collar workers, designers, artists, and local business owners. Most of them know each other from their workday visits and interact routinely with each other and with the saleswomen.

\section{Fig. 27}

Butcher's shop counter and a regular customer

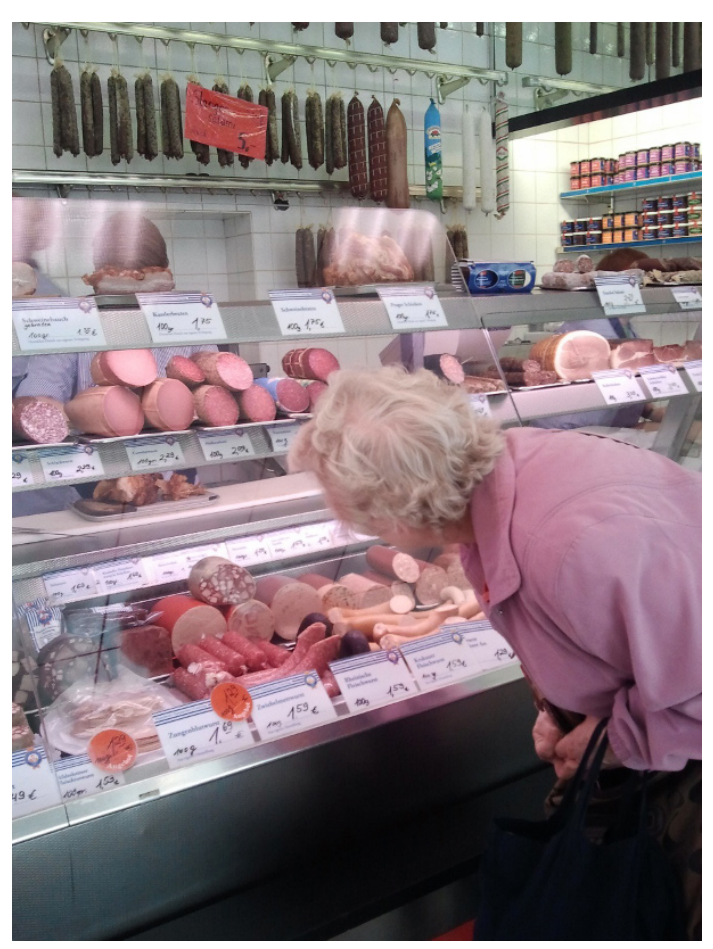




\subsection{Additional Cases and Conclusion}

The above presented five extensive case studies constitute my core sample of businesses along Karl-Marx-Straße. Selected by a theoretical sampling procedure (Glaser/ Strauss 1998,1967), they include gastronomic and retail facilities of smaller and larger sizes. Some offer seating and the invitation to spend more time in the shop and some do not; they include both longstanding and newer businesses with different degrees of local networks; they are owned by people of different gender, ethnic, and age groups; and the owners show varying senses of social responsibility for their businesses' local environments. ${ }^{151}$ This sample is by no means inclusive of all of Karl-Marx-Straße's past and present commercial establishments.

In addition to the detailed business cases described above, the field work also included three other core cases and surveys of several cafés and restaurants (which prima facie seem to fit Oldenburg's "classic" third place types), grocery stores, and the local shopping mall. In-depth interviews with almost all of these secondary case study store owners as well as extensive participant observation inside and in front of the businesses were conducted. Findings from this additional research serve to provide a context for and validation of the in-depth analysis presented in chapter 6 and 7.

The following summary provides background information on the businesses examined for this extended case material including details about the type of ownership, spatial design, staff, and customers. These descriptions give first insights to the ways in which business owners act as public characters and how their in-store social practices turn the businesses into third places (e.g. in terms of included customers, duration and strength of ties, and so on). Three of these businesses closed down during the time period in which I conducted my field work. This fact underscores the precarious situation that many small-business owners find themselves in over the course of urban renewal.

\section{Cafés}

Both cafés, which I will here call café I and café II, are owned by men. The owner of the first café is of Turkish descent and the owner of the other café is of German descent, and both have lived and worked on the street for many years. The owner of café I took over the business in 2007, at the time relying on customer networks that he had built in local restaurants where he had previously worked. The owner

151 Again, the sampling process was driven by the three sets of sensitizing concepts. The concepts of third place, public interaction, and public characters are thereby reflected in the key dimensions of the business types and their physical outlay. 
of café II took over the business in 1990, when the district government, which owns the building, decided to rent the café space to a public charity. Being a member of such a charity, the owner won the contract.

Both businesses are located in the cultural heart of Karl-Marx-Straße, in the same major $19^{\text {th }}$ century building complex as the local art-house cinema, opera, and theater. The businesses receive many customers by way of the cultural institutions and often organize after-show or pre-show events. Both businesses offer breakfast, lunch, dinner, and bar menus and remain open from the late morning through the evening and into the night. Foods and drinks tend to be cheaper here than in the newer bars, restaurants, and cafés in the area, partly because the district rents out the spaces, partly because the two owners want to serve primarily the local people, who they think are less wealthy than most visitors of the cultural institutions. Both cafés are on the ground floor of the rear buildings in this complex and both offer outdoor seating in their backyards, shaded from the sun and the noise of Karl-Marx-Straße.

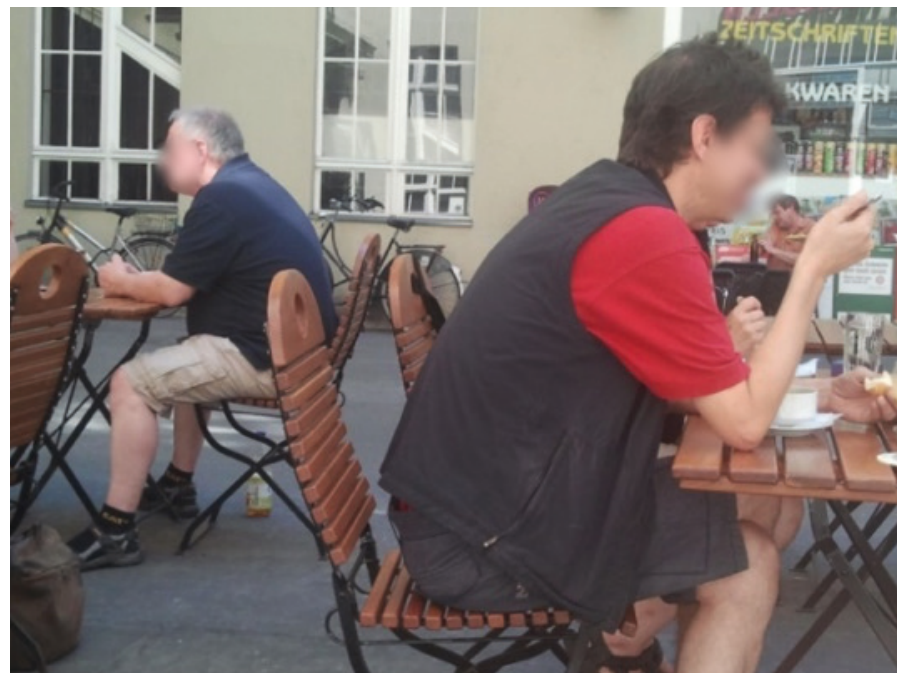

Fig. 28 Patio in front of café I

Both cafés are about $100 \mathrm{~m}^{2}$ with windows facing the backyards. Aesthetically similar, both cafés have dark golden painted walls, $19^{\text {th }}$ century coffee house stylistic references, dark leather benches, wooden interior furniture, and cozy artificial lighting. 
The atmosphere can be described as comfortable and relaxing. Many customers can be observed reading, studying, working, meeting business colleagues, or engaging in quiet conversations. Café I gets less sunlight and has fewer windows than café II and conveys a more sealed off impression.

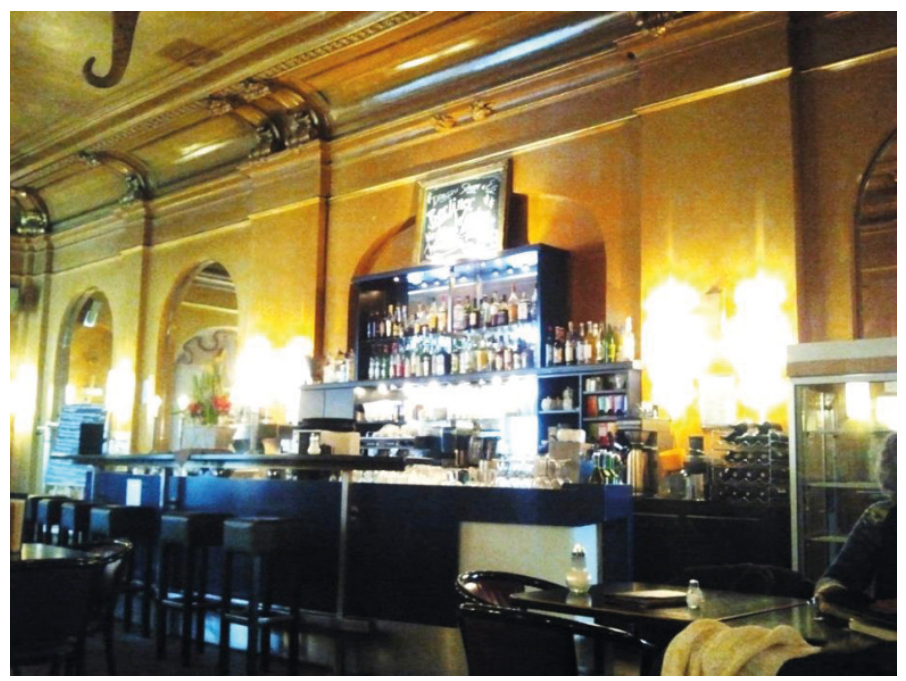

Fig. 29 Counter in café II

Compared to the other sampled businesses, both cafés benefit in different ways from their web presences. Both cafés have their own webpages and are also reviewed on numerous German and international gastronomic and tourist review websites (e.g. yelp or TripAdvisor). Therefore, some customers already have a good idea of what the cafés are like and how they foster or allow working, chatting, and so on.

Both café owners emphasize that they depend on visitors to the cultural institutions for their evening sales volume. Local residents and workers make up the majority of daytime customers. Many lunch- and coffee-customers also work in the building complex' opera, theaters, and cultural offices. These customers include designers, actresses, and technicians who do not only eat lunch in the cafés, but also frequent the cafés for meetings with colleagues during the afternoons and late mornings. In the evenings, theater and cinema-goers (often from other Berlin districts or beyond) frequent the cafés before or after the show. Compared to other local cafés, the clientele is more international. Tourists and newer residents (mostly 
from the US and Western or Northern Europe) mingle with locals, who mainly have German, Turkish, Polish, and Arabic backgrounds. The owners speak proudly of their educated customers, such as journalists, professors, or arts workers, some of whom have higher income backgrounds. However, a higher educational background does not imply higher spending habits, as per the owners.

The members of the service staff usually work part-time and either study or have a second job in addition to their regular hours in the cafés. They therefore tend only to be familiar with those customers who frequent the businesses on "their" days. Chatting and mutual teasing with colleagues and familiar customers are, however, still among their favorite practices. One owner (café I) jokingly describes his café as a "contact market" (1. 775), not only referring to couples that met in the café and later married, but also to his employees, who sometimes chat for more than 20 minutes with the customers instead of getting back to work. Employees and both owners have extensive local networks and are good friends with some of the customers. The owners know many local business people by name and regularly chat with them about work and family issues. They also host bigger events such as weddings or parties of other local businesses, which further expands their local networks. Due to their quasi-hidden location, these two owners have fewer complaints about Karl-Marx-Straße, its commercial structure, and the renovations than the other business owners located directly on the street. Both also appreciate the influx of new residents and "higher quality" businesses, hoping that the influx will result in a higher sales volume in their own businesses.

\section{Lunch restaurant}

I will call this establishment the "lunch restaurant" because it does the core of its business during lunch hours. The restaurant opened in 2009 when the workers' union, a provider of social services that owns the building, decided to open their own training restaurant rather than rent out the space. The restaurant has eleven employees (as of 2013), all of whom have or had a handicap and receive training from the workers' union for working in the food service industry. As a result, a comparatively high number of handicapped people also frequent the restaurant as customers. The business operations, however, are just like at any other restaurant.

The owner used to live in an adjacent neighborhood before he moved to a suburb in northern Berlin. He commutes to the restaurant five days a week. During his commutes and his emergency shopping trips to Karl-Marx-Straße, he frequently runs into customers. He considers these encounters beneficial for his business and his good mood. He is a socially responsible person, putting much effort into maintaining a friendly atmosphere in and around his restaurant. His elderly and handicapped customers receive particular attention-he spends time with them 
at their tables and helps them into or out of the restaurant. He goes so far as to call regular customers or their relatives, if the customer hasn't shown up for a while. Despite his long working hours, he takes his time for every customer in need. He can be observed reducing the price for (mostly non-regular) customers who do not have enough money to pay their bill. He also enjoys his role, which he describes as an "almost social service institution", gladly accepting packages, personal items, or keys for neighbors. This is how he keeps up to date with the local news and gossip. $\mathrm{He}$ is also well connected with neighboring shops and local business owners and uses these networks for additional business. The restaurant, for example, regularly delivers lunch packages to an adjacent business and caters their business events. These connections are for the owner, however, strictly business. He rarely spends his free time in the neighborhood. He complains that the area is too highly-trafficked, has too many low-quality businesses, and has a too homogeneous commercial structure. While other store owners see the local urban renewal measures in an ambivalent light, he generally welcomes the current urban renewal program.

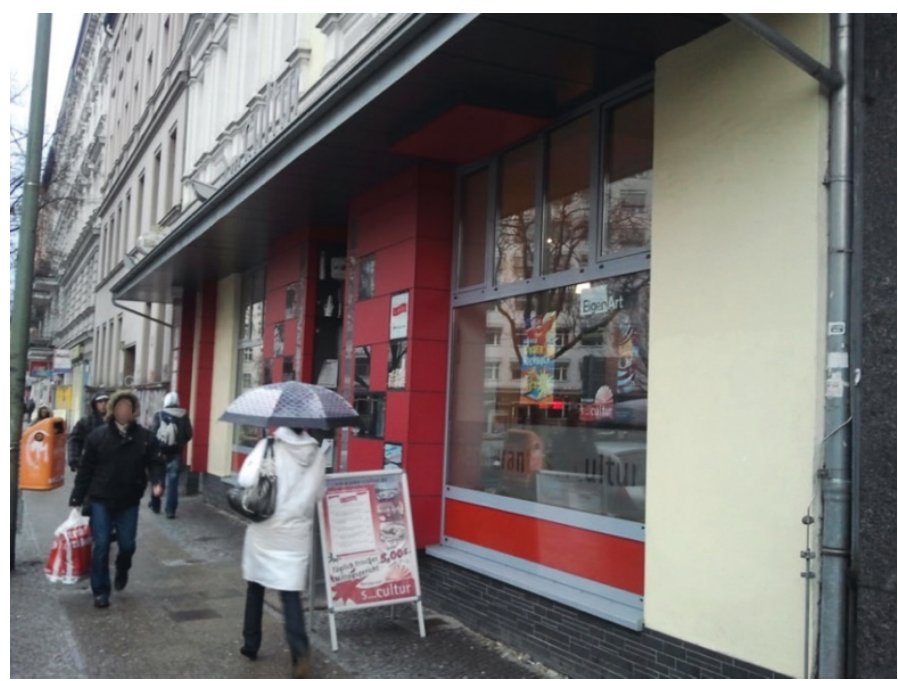

Fig. 30 Lunch restaurant's front window and sidewalk

The restaurant is located on the ground floor of a renovated early $20^{\text {th }}$ century building on a side street just a few steps away from Karl-Marx-Straße. The front window allows for a good view of the street and the adjacent square in front of the 
Neukölln town hall. The façade is designed in red and white colors and posters taped to the windows announce the weekly menus and special events, such as the monthly gourmet dinner. During the warmer months, the restaurant opens to a quiet $50 \mathrm{~m}^{2}$ back patio. Local employees and residents often meet there in the late afternoons and evenings for an after-work drink or dinner. The restaurant offers mainly traditional German food, made from local and seasonal products. The owner describes the lunch dishes as healthy and high-quality fast food.

Depending on the time of day, different customer groups can be found frequenting the restaurant. Employees from the local town hall and local offices, as well as some senior residents, come in smaller groups or by themselves during lunch time. Local residents tend to visit during dinner time. For the gourmet evenings, customers who are able and willing to spend money on good food come "from all over Berlin" $(1.286,500)$ to the restaurant. The customers have diverse ethnic backgrounds; however, during lunch time, most of the customers are of German or Turkish descent, as per the owner.

The vast majority of lunch customers is regulars and is often greeted by name. The staff members know the background information such as family issues, place of residence, food preferences, educational, and job backgrounds on nearly all of the regular lunch customers. According to the owner, the restaurant receives more and more "young people," "young entrepreneurs," and "students" (1. $92 \mathrm{ff}$.). The staff members tend not to know these newer customers as well, but consider them part of the changing neighborhood scene.

The restaurant receives only very few customers after lunch during the afternoons. During the busiest times of day - the limited time during local employees' lunch breaks - the main activities practiced by customers in the restaurant are eating, drinking, chatting. The observations show more extended and open-ended interaction during dinner times. The restaurant also hosts regular meetups, for instance for union members, colleagues, or language students. During such events, participants focus more on conversations and less on the food and its consumption.

\section{Fruit and Vegetable Store}

The fruit and vegetable store changed ownership three times during the course of my field work. Operated by the owners of the adjacent "Turkish"152 grocery store, both businesses had to finally close in early 2014, when the Turkish supermarket's

152 The business sign says Turkish supermarket. In Berlin, this type of grocery store usually sells (halal) convenience and fresh groceries and household wares made in Turkey and Germany. There are both chain and individually owned so-called Turkish supermarkets, most of which employ predominantly people with a Turkish migration background. 
lease was terminated and the building began undergoing renovations. The owners of the early $20^{\text {th }}$ century building had hoped to find commercial tenants who could increase the value of the building. ${ }^{153}$

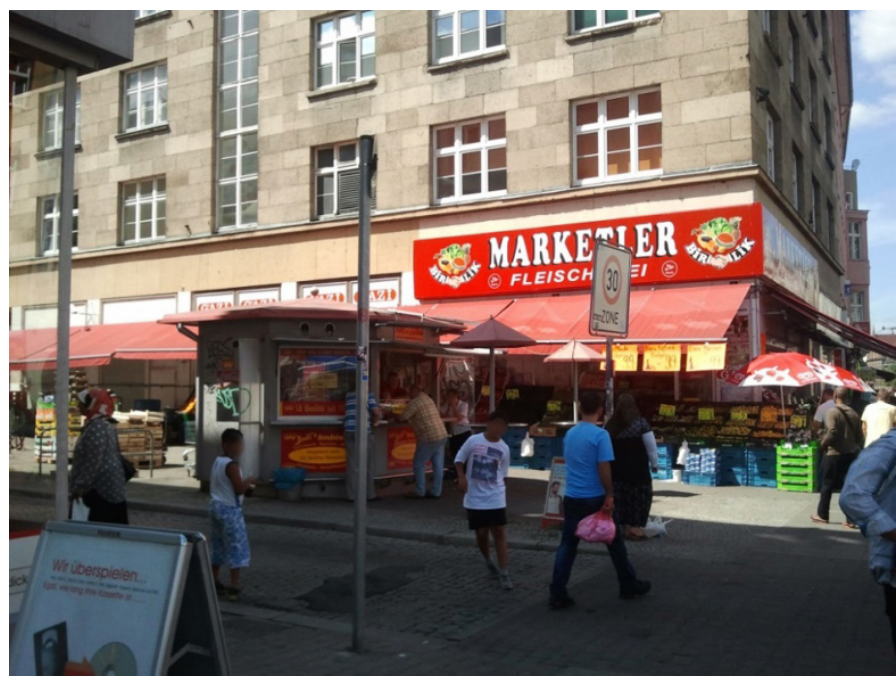

Fig. 31 Fruit and vegetable store building prior to renovations

The owner, who operated and worked in the shop until a few years ago, is the granddaughter of the couple who originally opened the store in the early 1950s. Back then, the business was a movable market stand which they parked a few meters down the street. The owner's parents took over the business in 1969 and expanded it to include other stands and permanent locations along the street. The owner joined her parents in the main business space when she turned 18 and finally took over the entire business when her parents fell ill in the early 1990s. At that time, the

153 In spring 2015, the ground floor was still unoccupied, although the renovations were finished. Since the owner of the building couldn't find an "appropriate" tenant, a German-Turkish chain-store finally took over the new business space and opened in May 2015. The upper floors were remodeled into loft-like apartments with new balconies. As of March 2016, some of the apartments on the upper floors as well as the former ground floor space of the fruit and vegetable store are still vacant, while the new supermarket seems to thrive. But in 2017, the supermarket had to close to another rent increase and as of September 2018, the store spaces are still vacant. 


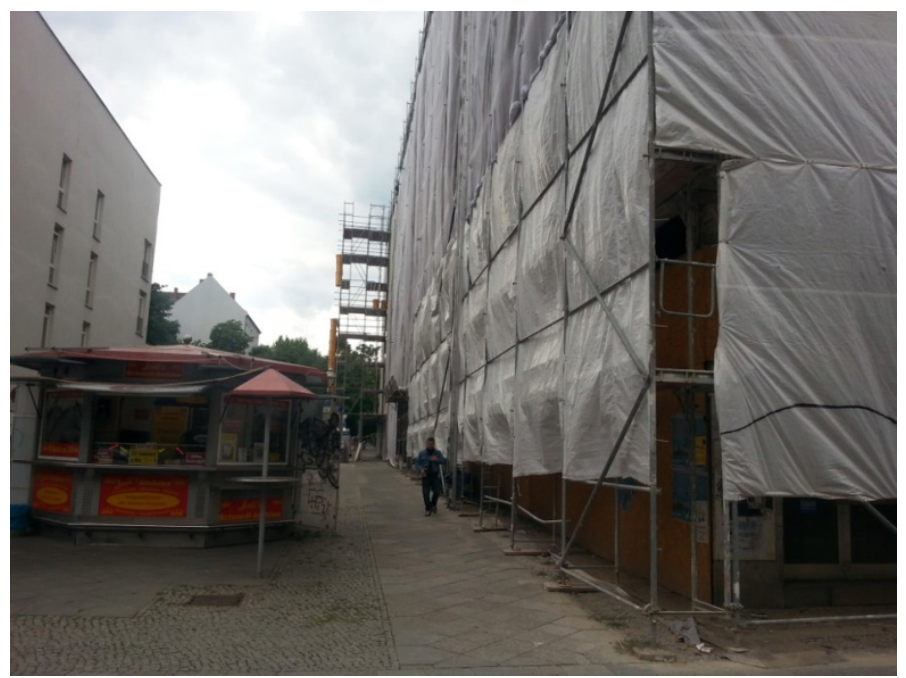

Fig. 32 Building under construction

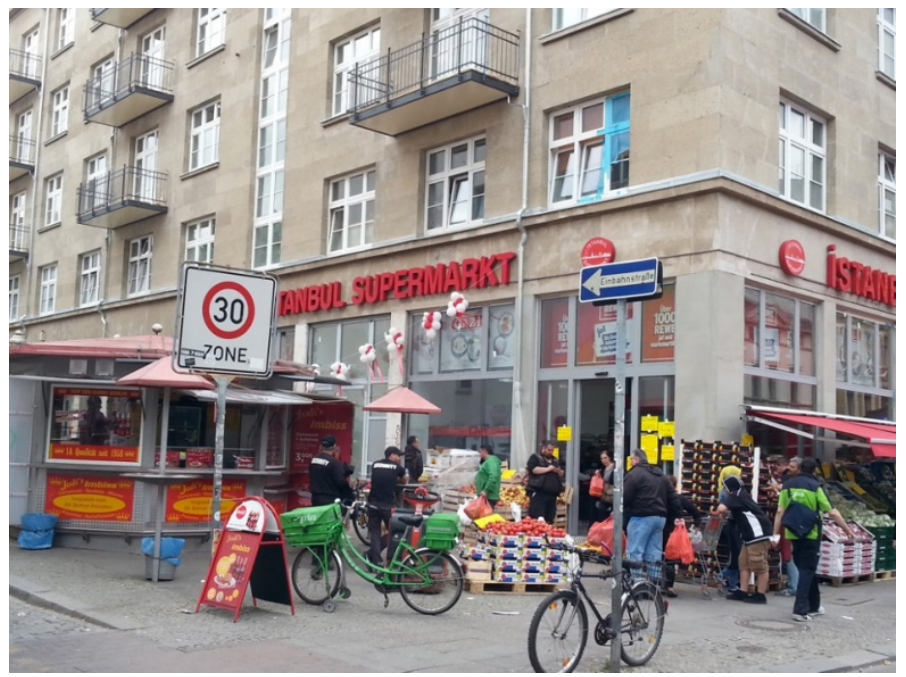

Fig. 33 Upgraded building with new supermarket 
store had 16 fully employed and long-term employees (mainly women). On weekdays, the entire staff sat together for a two-hour long lunch break, during which they ate and shared both private and business information and news. The business could be best described as a "traditional" family business; the employees were considered extended family members. The employees grew older with the business itself and most lived on the same block or very nearby.

Most regular customers also lived within walking distance: The majority was so-called stay-at-home mothers and women of German descent, who purchased fresh products in the mornings and afternoons to prepare lunches and dinners. Additional drop-in customers shopped during their commutes, often changing from the subway to the bus line that stopped in front of the building. When socalled guest workers ${ }^{154}$ moved to the neighborhood in the 1970s, the owners added Turkish and Mediterranean product lines. Their increasingly multi-ethnic clientele often exchanged recipes and cooking advice in the store; for special occasions, such as birthdays, regular customers brought cakes or cookies and regularly enjoyed a cup of tea or coffee with each other and the staff in the store. Before discount supermarkets and shopping malls changed the local grocery shopping patterns, the family business was renowned in southern Berlin. As per the owner, customers traveled from other parts of the district and city to get fresh fruits and vegetables specifically from the store.

However, when the owner took over the business from her parents, she faced increasing competition from discounters and chain supermarkets popping up in its immediate surroundings. This change was accompanied by an increasing demand for longer opening hours and a larger variety of fresh goods. Soon, the owner felt she could not stand up to these business challenges. Having grown up in the neighborhood with so many of her regular customers, she also felt a high level of social control when moving around in the neighborhood. Although she had always enjoyed interacting with customers, running into them on the street in Neukölln and in other districts, she couldn't stand the high level of social control, the exhausting work, and long hours, despite the customers' loyalty to the business after her parents died. Hence, when the local shopping mall opened and the bus line in front of her store was rerouted, she sold the business and moved to a North-Berlin suburb. She now takes care of her two children and supports her husband's unrelated business.

154 Germany had a guest-worker program, starting in the in 1960s until the recruitment ban in 1973. This program led to many Turkish workers moving to Germany and Berlin. Many settled in Neukölln in the following decades (Foroutan et al. 2015: 19 ff.). 
She still speaks proudly of her time as a business woman and considers herself a "real Neukölln person" (1. 524). She also keeps in touch with some of her former regular customers. However, she dislikes the current commercial landscape of KarlMarx-Straße and only comes to the neighborhood to visit her remaining relatives and the building she still owns. She bemoans the loss of the big department stores and specialty stores, the opening of the shopping mall, the traffic situation, and the neglected appearance of the street. Being a building owner, she welcomes the influx of new population groups, but is also highly skeptical of "yuppies," (1. 779) even if they might signify higher revenues for her.

Fig. 34

Fruit and vegetable store

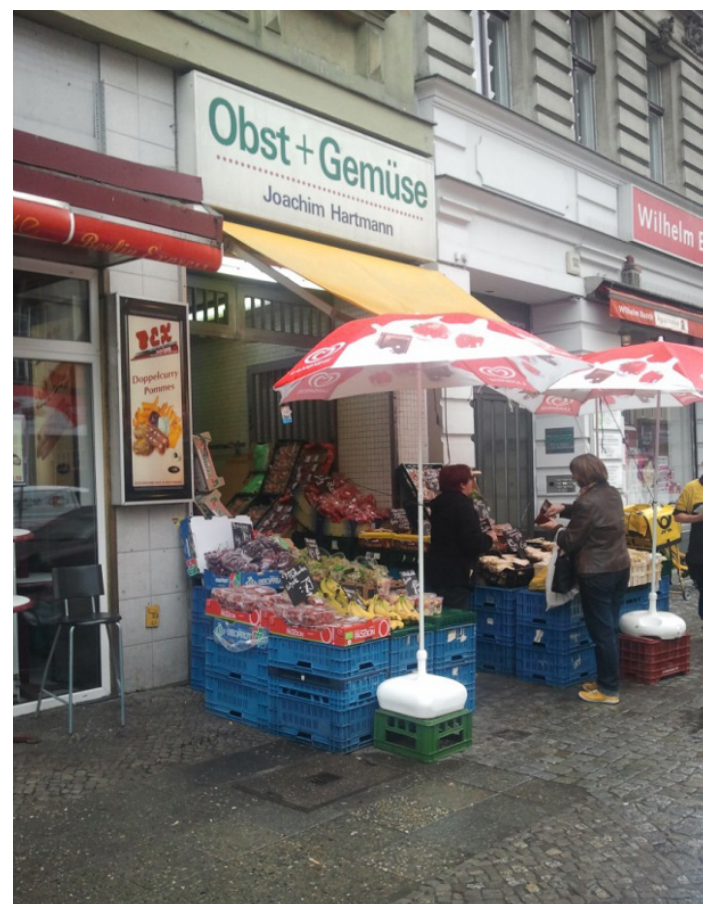

She sold the business in 2012 to the owner of the adjacent Turkish supermarket, who used the space to expand his shop. Her successor took over her few remaining employees, who continued to work there until they retired. From 2012 until late 2014, the clientele seemed to mirror the neighborhood's demographic structure: men 
and women of different ages, ethnicities, and lifestyle groups, many of whom came to the business on a regular basis. The salespeople's interactions with their regular customers did not change under the new ownership; they still greeted senior customers with a handshake, accepted postal deliveries for their neighbors, and the like.

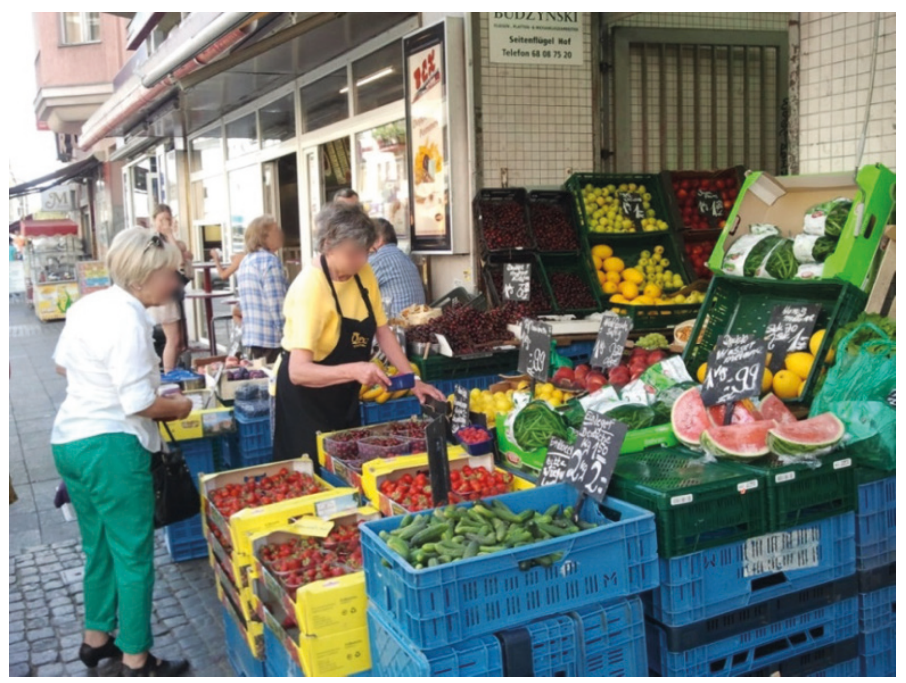

Fig. 35 Fruit and vegetable store

\section{Bar}

The bar, which closed in early 2014, was familiar to me even before I began my field work in 2012, because I had worked as a waitress in a nearby bar and restaurant for years. ${ }^{155}$ The bar was a somewhat hidden, small, corner bar. It was located on a narrow, tree-lined side street with the majority of buildings from either the pre-war era or the 1950s. Very few other businesses have been located on this street in recent years: a wine bar (that had to close down due to rising rents and a lack of foot traffic), a nail salon and a car repair shop (that both moved out when a new landlord increased the

155 In 2009, when our bar had to close because the landlord did not renew the lease, we looked for a temporary new space in the same neighborhood. Because we couldn't find an appropriate and affordable space in the first months, we looked for a place where we could maintain a weekly regulars' table in order not to lose our loyal, regular customers. 
rents), a kindergarten, and an insurance office. However, the street is closely connected with the business and traffic hubs at Karl-Marx-Straße and Hermannplatz.

The bar had holiday lights strung between the sidewalk trees and the entrance. One bigger and one smaller window looked out onto the street. There were three rooms inside. The main room was comprised of the bar and three little tables with bar stools. The second room had four tables decorated with lamps, 1960s-style tablecloths, plastic flowers, and menu cards. The third room was the largest, and had an antique pool table surrounded by six other tables. The restrooms were located behind the third room. The walls were painted green; and the furniture had a black and red color scheme. The antique, massive bar was painted red and crammed with all kinds of old-fashioned liquor bottles and an old porcelain tap. The ceiling was covered with stucco. The walls were covered with all kinds of decorations: porcelain dolls, harlequin masks, fans, paintings of befriended artists, self-drawn pictures, postcards from all over the world, photographs of regulars, concerts, and events dating back to the 1970s, photographs of the owner with local celebrities, and little presents the owner had received over the years. A corner of the bar was reserved for old records and books that were for sale, most of which are from the 1970s and 1980s. The owner and her husband were huge music fans, and the bar used to have weekly concerts and jam sessions, that gradually decreased in regularity over the years. The bar continued to occasionally host concerts until it closed, most of which from bands that were invited by regulars or partly consisted of regulars. The owner was also acquainted with most of the local record store owners, who visited the bar as well.

When we met, the owner was a confident, agile, and somewhat obstinate woman in her late $70 \mathrm{~s} .{ }^{156}$ Being a proud smoker, she had stopped riding the subway when the local transportation authorities prohibited smoking in 1974. She always had a cup of (mostly cold) coffee and a glass of tap water or alcohol-free beer in front of her as well as several crossword puzzles, leaflets, letters, postcards, and other paperwork. Born and raised in Budapest, Hungary, she fled to Switzerland and southern Germany in the late 1950s and finally moved to Berlin in the 1960s, where she started to work as a tailor. She had four husbands over her lifetime, some of whom died and some she divorced. She found her much younger, beloved, last husband in Berlin in the early 1970s. He died about ten years ago and she suffered this loss until her own death. His photograph decorated one wall of the bar, along with all kinds of souvenirs of him. She mentioned him in almost every conversion and it is clear that he was the main figure in her and well as the bar's life.

$156 \mathrm{My}$ former bar colleagues and I stayed in touch with her, even after her business closed in 2014, until her death in autumn 2015. 


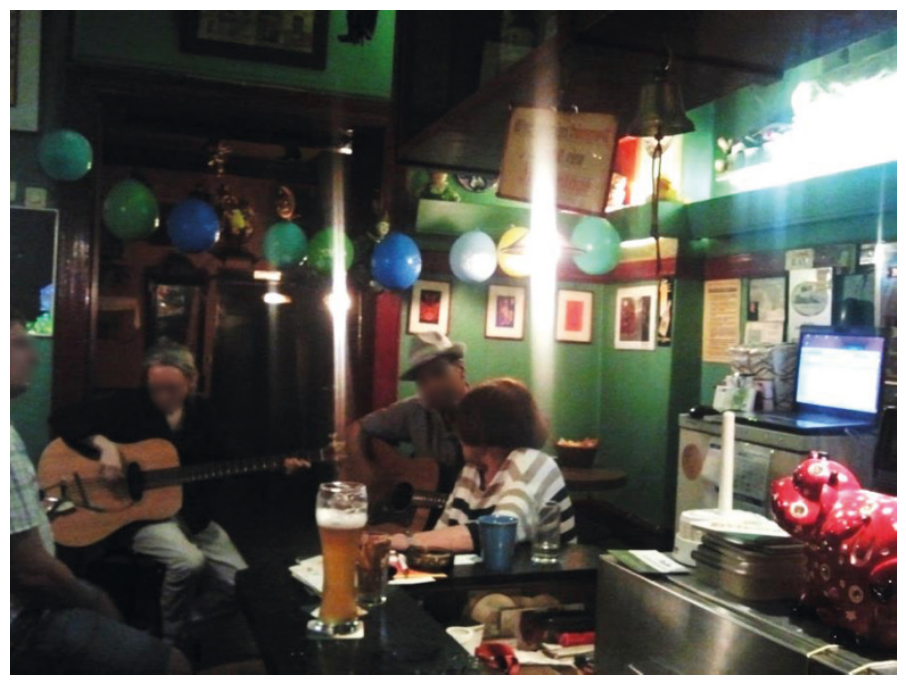

Fig. 36 The bar owner's last birthday party in the bar before the business closed

The two opened the bar together in the early 1970s and rented the apartment in the back, where they both lived. She gave up her previous job and started managing the bar's kitchen (selling classic Berlin bar food), and supporting her husband, who managed the bar in the front. Because she and her husband kept the bar open more or less every day for almost four decades, they almost never left the block. Even when her own mobility decreased, so many people came to the bar to share their information with her that she knew more gossip (about the residential and commercial changes and the local neighborhood news) than probably any other local. ${ }^{157}$

Most of her customers were locals. Some long-standing customers had moved to other neighborhoods, but many returned on a regular basis. The owner was well connected within the building as well, residents of two apartments in the building would often visit the bar and support the owner with little services such as going shopping for her. Former building residents also returned on a regular basis to visit the bar.

157 She knew the answers to questions like who opened what kind of business, who pushed whom out, which local politician was seen where and why, what kind of concerts take place where and when, where robberies and other crimes happened and by whom, where the new construction sites were, who the newcomers were and where they came from. Since she didn't use this information for her own everyday life due to her immobility, she mostly forwarded it to other customers whom she thought might need it. 
In the later years of the bar's operation, the owner employed a couple of waitresses and a cleaning woman (she wasn't paid, rather she helped at the bar out of friendship), who supported her with the bar's management and distributing drinks to the tables. The building was sold to a new real estate company that raised the rents and started to convert rental apartments into condominiums in late 2013. All businesses and tenants were forced to leave if they weren't able to buy their spaces. Operating the business as a single senior woman without savings, the owner was finally forced to give up her bar and retire. Afterwards, her health declined dramatically. ${ }^{158}$

\section{New café, shopping mall, hair salon}

Last but not least, my field work included spending a good deal of time in a recently opened (2014) "lifestyle" café, the local shopping mall, and a local hair salon. However, the owners of these establishments did not allow me to conduct interviews. ${ }^{159}$

\section{"New" Café}

I have deemed this new café a "lifestyle" café, because more or less the same lifestyle group frequents the establishment: The customers seem to belong to the same age group and seem to have the same aesthetic preferences and clothing styles. The café is busiest from the late mornings until the early evenings. The customers visit the café to eat lunch, to meet with friends or colleagues, and, above all, to study or work with their laptops. As per the waitress, the customers are men and women of mainly German, US-American, Turkish, and West and North European descent with similar educational backgrounds and consumption practices. They are generally between 20 and 40 years old. According to the waitresses, most customers are university students, who reside in the neighborhood, and so-called young entrepreneurs, who work locally in design or arts-related businesses. Tourists increasingly make up a larger part of the customer base. They mainly come for breakfast or brunch on the weekends.

158 Officially, the business is now a moving and liquidation business, but it practically served as a club café for Turkish men after the closure of the bar. In early 2015, the business was turned into a Greek men café. Only some of the former regulars found a new meeting place. After her death in 2015, I talked to some of them and they are still bemoaning the loss of their "living room," "center," "where it all came together." Most don't go out as often as before due to the lack of a new regular space or their difficulties to become a regular in a new bar.

159 I also conducted limited participant observations in a local kiosk, a kebab takeaway, and a cell phone store. However, the reluctance of the owners to participate in the study and the spatial design of the stores did not allow for extensive observations without the permission of the owners and staff. 


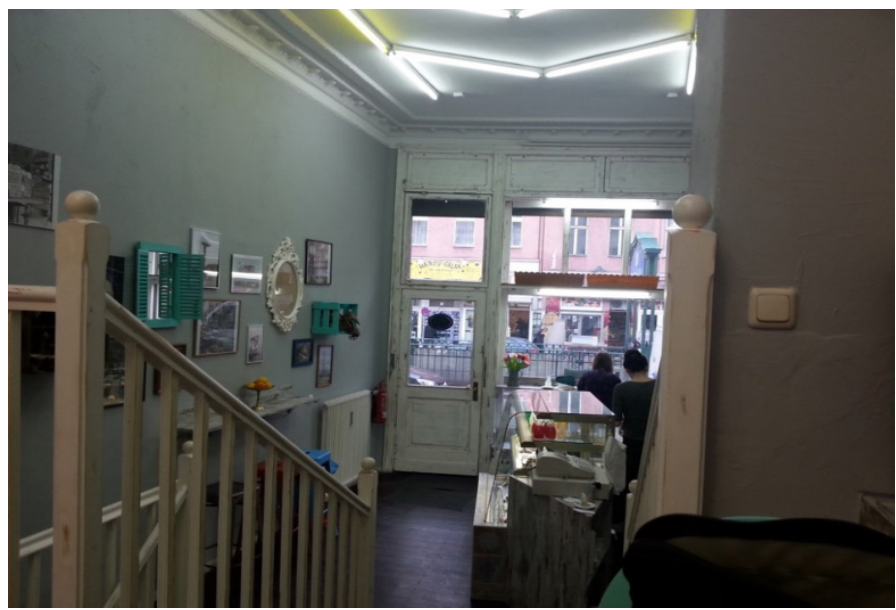

Fig. 37 View of the new café from the back room

The café is one of the first on Karl-Marx-Straße to offer free Wi-Fi and appeal directly to an English-speaking target group. ${ }^{160}$ The menu is written in English with German subtitles. They offer mostly German and Turkish food and beverages, which are priced slightly higher than in the adjacent cafés and bakeries. They also offer mostly vegetarian, vegan, and organic options. The business opens to the street with a window front, along which a table and bench allow customers to be watched from and to watch the street while they consume. This is a major difference from the other two investigated cafés that are either set back from the street in backyards or open to the back.

The café has three floors, which, along with the country-style furniture, give off a feeling of a private apartment. In 2014, the bar presented itself both to the street and in social media as a "soul food restaurant." They advertised their Mediterranean menu, vegan and vegetarian selection, catering, and special events held at the café. The owner is of Turkish descent. He explicitly targets the growing number of tourists and international users of the street. Although customers tend to spend a significant amount of time in the business, I rarely observed unplanned encounters or interactions with other customers. Most customers appeared to be preoccupied

160 On a restaurant review homepage, customers describe the business as "pioneering," "hip," "newly designed," and "chic." And "I see, another stylish hipster-shop in Neukölln (at least on Karl-Marx-Straße, wherewith they show a little pioneering spirit)" (01/22/2014). 
with their work or friends. However, during lunch time, regular customers chat familiarly with the employees. The staff is mostly female and between 20 and 30 years old. Most work only part time in the café and live in the adjacent neighborhoods. Despite the relatively short business history, the staff and owner have already developed ties with regular customers and vice versa.

\section{Shopping Mall}

A major anchor for the Karl-Marx-Straße commercial district is a shopping mall constructed in 2000 (see more in Chapter 2). With around $27,000 \mathrm{~m}^{2}$, it houses more than 50 businesses on five floors, most of which are chain stores that sell clothes, shoes, books, electronic devices, home decorations and furniture. Several fast food restaurants, cafés, bakeries, a bigger supermarket, a postal office, banks, and drug stores are also located in the mall. The upper floors contain additional franchise and chain businesses, a parking garage, a municipal library, a fitness studio, and a multiplex cinema, which draw additional customers to the mall. As mentioned, Karl-Marx-Straße was home to several large department stores in the distant past (cf. Chapter 2). Throughout the 1990s, the district government of Neukölln debated about whether to support the new shopping mall instead of the local warehouses. Finally in September 2000, the mall opened, despite the resistance and critique of local small business owners. Due to the low purchase power of local residents and the mismatch between what the shops in the mall initially offered and what the residents could buy, the mall was resold and remodeled in 2003. Since then, it has begun catering more directly to residents of Neukölln and the adjacent neighborhoods.

An expansive bar and community garden also opened on the roof of the parking garage after much encouragement from the local urban renewal program, City Management, and mall management in June 2013. Promoted as an "artistic and cultural roof garden" with a spectacular view of the entire Berlin cityscape, the bar also occasionally hosts events such as concerts and dance parties. This "hipster bar" draws additional customers (who differ from the usual mall users) to the shopping mall.

After the rooftop bar opened in early summer 2013, tourists and nightlife visitors frequent the mall more often. As per my observations, the everyday shoppers mostly use the main door next to the subway stop, whereas the bar guests seem to use mostly the back door that leads directly to the elevators. Therefore there is little interaction between these two customer groups. Rather, interactions occur mostly between the bar guests and library users, car drivers, and senior customers in the spacious elevators. 
Fig. 38

Shopping mall, as seen from the outside

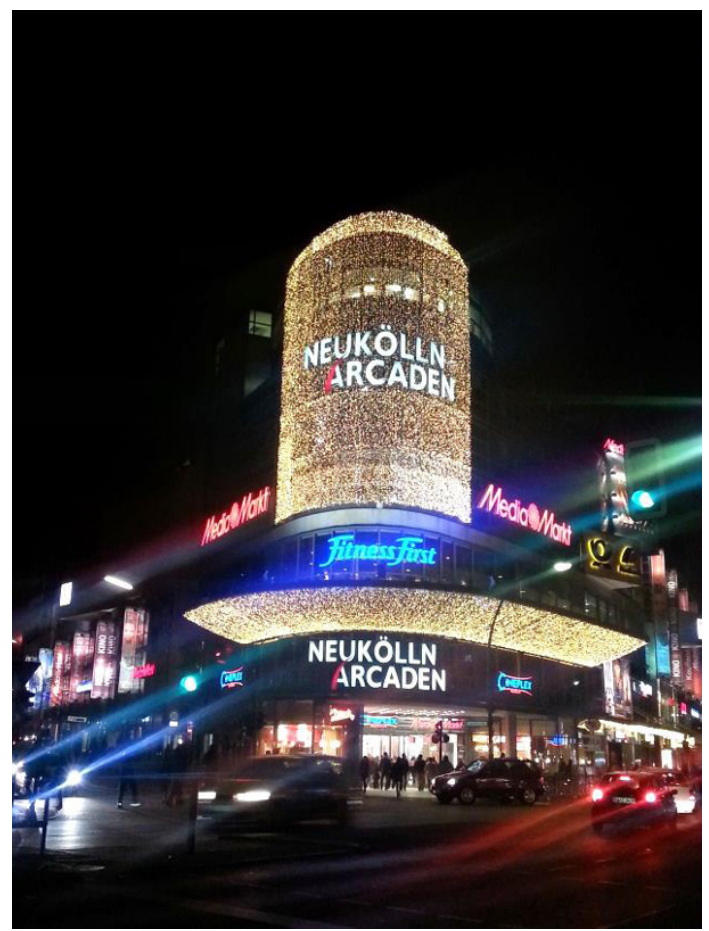

Local teenagers and senior residents also hang out at the shopping mall, a practice which is widely accepted by the mall's security guards. The mall is particularly crowded during the colder months and rainy seasons, to the disfavor of the other business owners along Karl-Marx-Straße. The mall also participates in local cultural events. For example, it provides exhibition space and also sponsors an annual fashion show for local designers and artists. The owner of the mall sponsors some of these events and also pays its staff overtime hours to work at these local community and business meetings. This logistical support gives the mall a structural advantage in these meetings compared to individual business owners who must attend on their free time, often without a direct financial benefit. The mall's managers spend a significant amount of time lobbying for the interests of the mall and have successfully worked together with the local district authorities, the urban renewal program and particularly the local City Management team. 


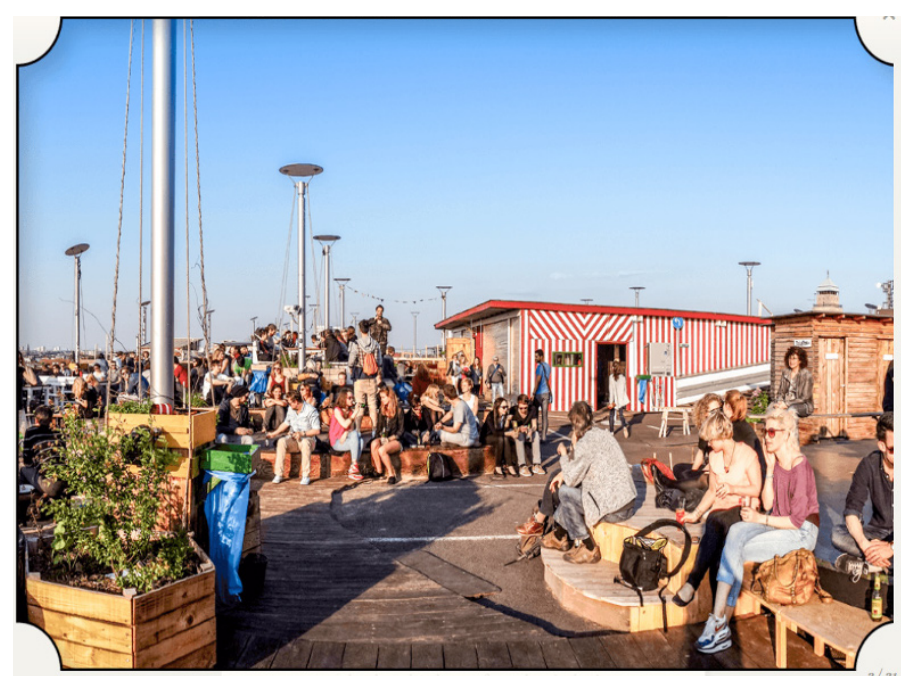

Fig. 39 Screenshot of rooftop bar's homepage ${ }^{161}$

\section{Hair salon}

The hair salon was originally opened in 1955 on a side street of Karl-Marx-Straße. After two moves, the business settled in its current location on a different side street, just a few steps from Karl-Marx-Straße, in 1973. It is currently owned and operated by the daughter of the original owners-a well-kept woman around 60 years old, who, despite being the full owner and spokesperson of the salon, constantly mentions her husband as being the one who makes the business decisions. All of the members of the family used to work together in their salon until the owner's sister and her son opened their own businesses in other Berlin districts and the grandparents retired.

The store can be best described as a classy, old-fashioned salon. The wall décor is neat and tidy; beige and gold carpets line the floors; the seating is leopard-print; and the shampoos and cosmetics are high-quality and expensive. The well-groomed employees call their business "exquisite" and converse in the old, cultivated way, which seems to please the observed customers. Customers are served with coffee and snacks during their appointments and chats are common between the regular clientele and long-term employees. The owner places high value on her business' long history in the neighborhood and proudly speaks of her customers, many of

161 Courtesy: Neuköllner Kranichgesellschaft mbH. 
whom are male workers in the local administration, politicians, or business people, and their wives. According to my observations, most are of German and Polish descent. According to the owner, the salon also attracts wealthier customers and particularly local business people of Turkish descent, so she also employs hairdressers of Turkish descent.

During my observations, most customers stayed for at least for 30 minutes, regardless of whether they got a haircut, a hairstyle, or just came for a chat or to make an appointment. These customers were mostly well-dressed women over 50, who spoke with the local accent and sported elaborate hairstyles (e.g. teased perms).

The staff is well trained and offers excellent service; however, the products and services are more expensive than in many other local hair salons. Compared to the other local hair salons, this salon also specializes on "traditional" haircuts and other services (e.g. classy pinned-up hair styles or perms). In my phone interview with the owner, she said that her business struggles to maintain its clientele, since many senior customers have already passed away or moved away to retirement homes. She also claimed that the new customers in the neighborhood seem to prefer cheaper or more "hip" hair dressers.

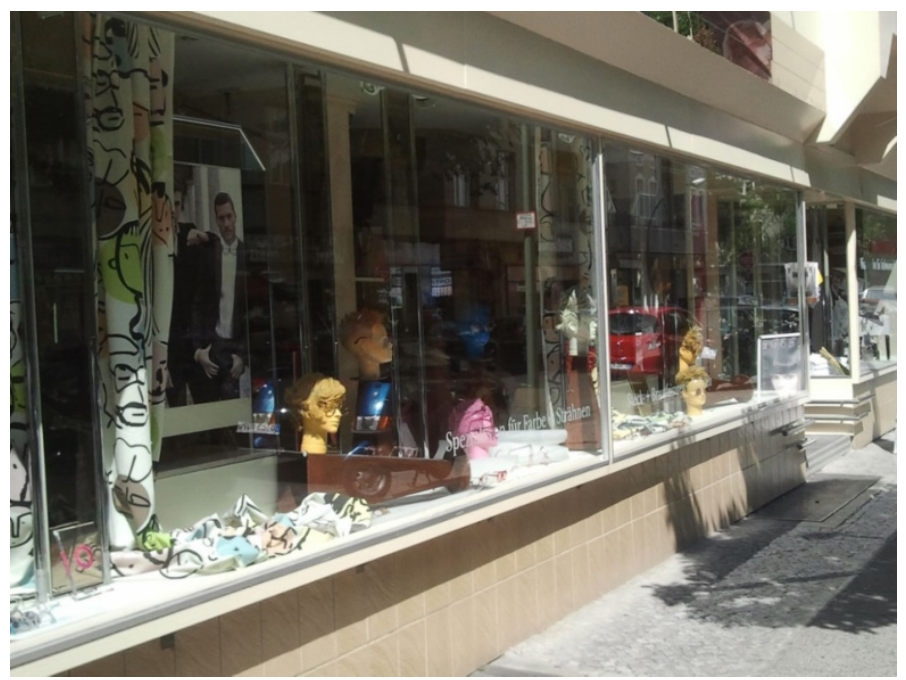

Fig. 40 Window of the hair salon 
Although we had already talked several times on the phone, the owner canceled our interview shortly before we were supposed to meet in her store. She sounded hesitant, shy, and suspicious on the phone, even though I had known her to be an outgoing person and a leading local business woman. She explained that she had talked to her husband and that they both decided that they were not willing to meet for an interview. But first and foremost, she mentioned that their business is experiencing troubles "due to all these changes here" and that she has "some serious problems." My understanding of the competing businesses (so-called 10Euro, "Turkish," and hip "lifestyle" hair salons, also named by the owner) suggest that mainly the store's aging regular customers and old-fashioned design mean a loss of sales (despite the well-trained and up-to-date staff) rather than the street's bad reputation. When I asked about the kind of problems and offered my help to her, she repeated "Yes this kind of changes that are going here, our business is not running well, and things get broken." She was reluctant to go into further detail and sounded desperate. She asked if:

the interview [is] about Karl-Marx-Straße? I don't want to add to that. It doesn't help us. I'm afraid that I can read my name somewhere in a published text. This is too much of insights into my business. I am afraid that I lose even more by talking to you. I am so sorry. But I am afraid. We really struggle. ${ }^{162}$

She also refused to allow me to conduct further observations in her business-in part because she seemed ashamed of the loss of customers and in part because she feared that my writing might turn off any remaining potential customers. However, we did have several, comprehensive conversations on the phone, which revealed that she is not coping well with the demographic changes in the neighborhood. She is unwilling to adapt to new customer demands or to reduce her prices; and she fears she will need to lay off some of her long-term employees. However, she welcomes the installment of the City Management program and considers it as helping her to further operate her salon successfully - neglecting the City Management's focus on new "hip" cafés, restaurants, galleries and boutiques, and their gastronomization of the street. She does advertise her business locally, particularly in the urban renewal program's published material. However, these advertisements highlight features

162 I offered anonymization to all of my interviewees (with the exception of this owner, all rejected). Although I repeatedly reassured her that neither her nor her business' name would appear in any published material, she replied that she feels too embarrassed to let anyone into her formerly renowned and prosperous salon. However, and to my surprise, after my calls, she gave an extensive interview and allowed photographs of her and her salon to be included in the local City Management's publication. 
that do not necessarily match the taste and demand of the long-term low-income residents or the new residents. ${ }^{163}$

\section{Conclusion}

The sensitizing concepts of "public interactions" and the "public realm" (Lofland, Goffman), "third places" (Oldenburg), and "public characters" (Jacobs), as well as other dynamics that may generate "community," led me to examine different kinds of businesses, ranging from chilly, small places to warm, comfortable, large ones. Data from participant observations and in-depth interviews provide not only a historical and geographical tour of the selected businesses, but also a broader understanding of the people who work and consume in this commercial district. ${ }^{164}$

Because most Neukölln households do not own an automobile and there is very little need to visit other districts (whether for employment, schooling, or leisure), many residents around Karl-Marx-Straße spend much of their time locally. ${ }^{165}$ The average amount of time customers spent in these businesses varies widely depending on the type of business. These time frames range from two hours or more in the bar or the main cafés, to 30 minutes in the lunch restaurant, butcher shop (during lunch time), or flower store, to less than ten minutes in the pharmacy and vegetable store. As shopping increasingly becomes a means to express one's identity, men are more likely to visit businesses that used to be occupied more with female shoppers (e.g. cafés, shopping malls, grocery stores). The observations and the owners' descriptions of their customers show that men seem no less consumption-oriented than women. On the other hand, in the past, many bars or pubs in Neukölln ${ }^{166} \mathrm{imposed}$ strong customary barriers to participation by (single) women (Walters/ Broom 2013:

163 The owner had to close her store in late 2015, after the fieldwork has ended. The new owner is a hairdresser of Turkish descent, who describes her business as offering upscale haircuts and makeup, particularly for "Turkish weddings."

164 I consider working and consuming to be the two "main" or most obvious, but not only, social practices.

165 Less than 200 of 1000 inhabitants own a car in northern Neukölln. See: Berlin - das Hauptstadtportal (n.d.). Berlin Verkehr in Zahlen 2013, http://www.stadtentwicklung. berlin.de/verkehr/politik_planung/zahlen_fakten/download/Mobilitaet_dt_komplett. pdf, accessed 04/27/2016.

166 Most long-standing bars can be best described as typical working class neighborhood bars or corner bars, in other words, places for sociability among male (blue-collar) workers. The bars that opened after 2006, the date to which most interviewees refer to as the start of gentrification, pose not only less physical or social barriers to women, but target them directly as an important and potentially affluent clientele (e.g. offering drinks, lighting, music, furniture and a behavioral codex that the respective staff perceive as conducive for women customers). 
197). Other reports from the interviewees (and my own observations in the early 2000s) suggest that most local businesses were largely the realm of women in their daytime manifestations, whereas male sociability used to dominate the bars and nighttime consumption places, with strong norms of behavior evolving around the consumption of beer until the 2010s (cf. Walters/ Broom 2013: 189).

Now, however, such bars receive as many women as men, according to my observations and the businesses' staff. Today, with the exception of the flower store, none of the businesses receive significantly more women than men. However, as the portraits reveal, the stores are still gendered places at certain times of day. For example, the butcher shop tends to be male dominated during lunch time and the flower store is female dominating not only during the coffee klatch. The increase in single households and employed women has also generated more customers for the here examined grocery stores, butcher shop, and main café.

In sum, the social phenomena of daily shopping, eating, and drinking have become widespread across lines of gender, class, ethnicity, and age on Karl-MarxStraße. With this said, the descriptive-explanatory portraits of the sampled stores serve as the socio-spatial and narrative context for the following analysis chapters on first, the businesses' features that increase the in-store interaction and sociability and their origins in practice, and on second, the store owners' social practices that turn their businesses into spaces where community is practiced.

Open Access This chapter is licensed under the terms of the Creative Commons Attribution 4.0 International License (http://creativecommons.org/licenses/by/4.0/), which permits use, sharing, adaptation, distribution and reproduction in any medium or format, as long as you give appropriate credit to the original author(s) and the source, provide a link to the Creative Commons license and indicate if changes were made.

The images or other third party material in this chapter are included in the chapter's Creative Commons license, unless indicated otherwise in a credit line to the material. If material is not included in the chapter's Creative Commons license and your intended use is not permitted by statutory regulation or exceeds the permitted use, you will need to obtain permission directly from the copyright holder.

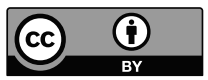

